\title{
INTERTEXTUÁLIS UTALÁSOK II-III. SZÁZADI PHRYGIAI SÍRFELIRATOKON
}

\begin{abstract}
A Közép-Anatóliában fekvő Phrygia nagy történelmi múlttal, sajátos nyelvvel és kultúrával rendelkező térség volt a Római Birodalomban, ahol az írásbeliséget és az irodalmi műveltséget igen sokra becsülték. A Kr. u. II-IV. század közötti időszakból több száz görög nyelvű epigráfiai emlék maradt ránk, amely mindezt tanúsítja. A síremlékeken feltűnően nagy számban ábrázoltak írótáblákat, tolltartókat és papirusztekercseket, és sehol másutt nem került elő ennyi verses sírfelirat, melyeknek szinte mindegyike zsúfolásig tele van homérosi reminiszcenciákkal és klasszikus mitológiai utalásokkal. Mindez ráadásul nemcsak a városok, hanem a rurális területek lakói - többnyire egyszerű földművesek és állattenyésztők - körében is egyformán jellemző. Az epikus nyelven fogalmazott verses epitáfiumok a görög-római vallás hívei és a keresztények között is népszerüek voltak. Az utóbbiak természetesen bibliai idézetekkel és allúziókkal is bővítették irodalmi repertoárjukat, ráadásul már nagyjából másfél száz évvel a konstantini vallásbéke előtti időszakban.
\end{abstract}

Kulcsszavak: Phrygia, epigráfia, verses sírfeliratok, intertextualitás, írásbeliség, Homéros, Biblia

\section{Bevezetés}

A Római Birodalom nyugati és keleti fele között az egyik legszembetűnőbb kulturális különbség az volt, hogy az utóbbiban az írásbeliség a római hódítás idején már sok-sok évszázados múltra tekinthetett vissza. Az egyiptomi, föníciai, zsidó, görög és számos kis-ázsiai nép is sajátos írásrendszereket alakított ki, amelyeken keresztül létrehozta saját irodalmát, és müködtette saját államszervezetét. A Római Birodalom égisze alatt ebben nem is történt változás, hiszen a hódítók nem erőszakolták rá saját nyelvüket a meghódítottakra, sőt, keleten ők maguk is a görögöt használták közvetítőnyelvként, és saját idiómájukat továbbra is használhatták az őslakosok. ${ }^{1}$ A Nerva-Antoninus-dinasztia időszakát (Kr. u. 96-192), továbbá a Severusok korát (Kr. u. 193-235) már eddig is az ókori római történelem virágkorának tartotta a kutatás - legalábbis ami a gazdaság és társadalom helyzetét illeti. Nagyjából negyedszázada ismerték fel, hogy ugyanebben az időszakban az írásbeliség (literacy) valóságos robbanása ment végbe a Birodalomban. Óriási mértékben megnőtt az íráshasználat intenzitása, mégpedig mindenütt: a viszonylag fejletlen északi peremterületeken éppúgy, mint az évezredes írásbeliséggel rendelkező népek körében. ${ }^{2} \mathrm{Az}$ alábbi tanulmányban egy olyan területet vizsgálok meg ebből a szempontból, amely sok tekintetben egyedülálló a Római Birodalomban.

1 Adamik B.: Nyelvpolitika a Római Birodalomban. Budapest (2006), vö. G. Woolf: Monumental Writing and the Expansion of Roman Society in the Early Empire. JRS 86 (1996) 22-39. A többnyelvűségről lásd R. MacMullen: Provincial Languages in the Roman Empire. AJPh 87 (1966) 1-17; J. Clackson: Language Maintenance and Language Shift in the Mediterranean World during the Roman Empire. In: Multilingualism in the Graeco-Roman Worlds. Eds. A. Mullen - P. James. Cambridge (2012) 36-57.

2 A. K. Bowman: Literacy in the Roman Empire: Mass and Mode. In: Literacy in the Roman World (JRA Suppl. 3). Eds. M. Beard - A. K. Bowman - M. Corbier. Ann Arbor, MI (1991) 119-131; K. Hopkins: Conquest by Book. In: ibid. 133-158. 


\section{Egy történelmi régió: Phrygia}

Phrygia az Anatóliai-fennsík nyugati végét elfoglaló földrajzi térség, amely a bronzkorban Muska néven volt ismert. ${ }^{3} \mathrm{~A}$ későbbi korokban a régiót északon Bithynia, nyugaton Mysia, Lydia és Caria, délen Lycia, Pamphylia és Pisidia, nyugaton pedig Lycaonia és Galatia határolta. A római hódítást követően Phrygia legnagyobb része Asia, kisebbik része Galatia tartományhoz került, így az ősi phrygiai főváros, Gordion is. A történelmi régi-

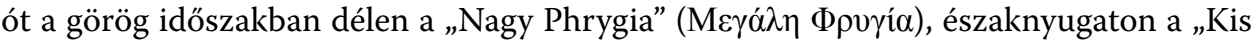
Phrygia” (Mıкра̀ $\Phi \rho v \gamma i ́ \alpha)$ részekre tagolták. De ezen belül is léteztek sajátos térségek, például Phrygia Epiktétos és Phrygia Paróraios. ${ }^{4}$ A Diocletianus által Kr. u. 301-ben bevezetett közigazgatási reform három részre osztotta: Phrygia Salutaris keleten (Synnada fővárossal), Phrygia Pacatiana nyugaton (a Lykos-menti Laodikeia fővárossal), Phrygia Combusta pedig középen (Laodikeia Combusta fővárossal) terült el. A Salutaris, vagyis „egészséges” nevet a régió bővízű hőforrásairól és gyógyvizeiről kapta (Hierapolis

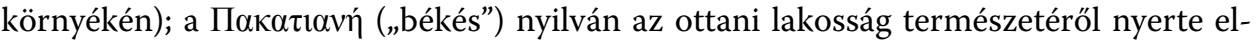

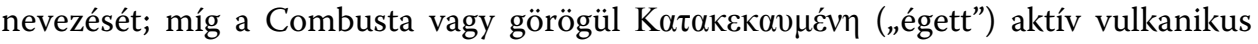
tevékenységre, illetve vulkanikus eredetű talajra utal. ${ }^{5}$ Ez utóbbi kiváló szőlőtermő vidék volt, amelyet már Homéros is $\Phi \rho v \gamma i ́ \alpha$ $\alpha \mu \pi \varepsilon \lambda o ́ \varepsilon \sigma \sigma \alpha-$ nak nevezett (Hom. Il. III, 184), s ahol - a feliratok tanúsága szerint - „szőlőszeretők” ( $\varphi \imath \lambda \alpha ́ v \pi \varepsilon \lambda o \imath)$ néven társulat is alakult. Az itteni síremlékeken a szőlővessző és szőlőfürt, valamint a falx vinitoria az egyik leggyakoribb motívumnak számít, s ugyaninnen Dionysos tiszteletére állított oltárkövek is nagy számban kerültek elö. ${ }^{6}$

Az ősi phrygek a görög történeti tradíció szerint a Balkán-félszigetről vándoroltak be Anatóliába. ${ }^{7}$ Legendás királyuk, Midas alapította első fővárosukat, Gordiont. (Egy

${ }^{3}$ A Muska (Muski vagy Moschoi) nevet asszír források tartalmazzák, és csupán egy-két poszthettita dokumentumból ismerjük (például Yairis felirata Kárkemisből, Kr. e. VIII. század, CAH III/2, 623), egy 2019-ben előkerült luwi nyelvű feliraton említették Hartaput mint Muska meghódítóját, lásd P. Goedegebuure et al.: TÜRKMEN-KARAHÖYÜK 1: A new Hieroglyphic Luwian inscription from Great King Hartapu, son of Mursili, conqueror of Phrygia. AS 70 (2020) 29-43. Valószínű, hogy a Tórában említett Mések (1Móz 10:2, 1Krón 1:5) erre a népnévre utal. A mai grúzok (georgiaiak) és örmények egyaránt ide vezetik vissza eredetüket: A. V. Kossian: The Mushki Problem Reconsidered. SMEA 39 (1997) 253-266.

${ }^{4}$ Strabón XII, 4, 1 C 563; W. M. Ramsay: The Historical Geography of Asia Minor. I. London (1890) 150.

${ }^{5}$ A terület történeti földrajzát máig érvényes módon feldolgozta: Ramsay: $i . m$. (4. j.), lásd még uő: The Geographical Conditions Determining History and Religion in Asia Minor. GJ 20 (1902) 257-275; S. Mitchell: Anatolia. Land, Men, and Gods in Asia Minor. Volume I: The Celts in Anatolia and the Impact of Roman Rule. Oxford (1993) 143-147.

6 SEG XXXI, 1130 (császárkori); SEG XLVI, 1493 (Kr. u. 161/162), vö. H. Malay: Filanpeloi in Phrygia and Lydia. EA 38 (2005) 42-44. A phrygiai szőlőtermesztésről: M. Waelkens: Phrygian Votive and Tombstones as Sources of the Social and Economic Life in Roman Antiquity. AnSoc 8 (1977) 277-315; L. Robert: Documents d'Asie mineure. BCH 107 (1983) 497-599, kül. 541-542. A falx motívum gyakoriságát lásd Waelkens: $i$. m. (6. j.) 280-281.

7 Hdt. VII, 73; VIII. 138. Ezt a migrációtörténetet a modern kutatók közül többen is vitatják, lásd például K. Kopanias: The Mushki/Phrygian Problem from the Near Eastern Point of View. In: Nostoi. Indigenous Culture, Migration and Integration in the Aegean Islands and Western Anatolia During the Late Bronze and 
másik Midast - Mita néven -, aki a Kr. e. VIII. században élt, asszír forrásokból ismerünk. ${ }^{8}$ ) Az Ilias szerint a phrygek Ilion szövetségesei voltak a trójai háborúban. A phrygek az indoeurópai nyelvcsaládhoz tartozó saját nyelvet beszéltek, amely elég közel állt a göröghöz és a thrákhoz. A paleo-phryg nyelv első emlékei Gordion környékén kerültek elő a Kr. e. VII. századból, majd az írás eltűnik a Kr. e. III. századtól kezdve. Érdekes jelenség, hogy a görög betűkkel, de ún. neo-phryg nyelven írt szövegek a Kr. u. I-III. század között tűnnek fel, eddig összesen 129 darab ismert belőlük, kizárólag sírfeliratokról Phrygia északkeleti részéből, valamint a Lykaoniával és Galatiával határos területekről. ${ }^{9}$ Phrygia soknemzetiségü, soknyelvü terület volt, és maradt is a római korban. ${ }^{10}$ Kolossaiban egy I-II. századi síroltáron került elő a „Markosnak, Markos fiának, a kolossaibeliek

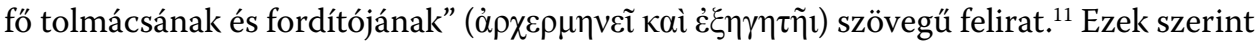
Kolossaiban nem is egy tolmács müködhetett, ha volt „fö” tolmácsuk; de hogy diplomáciai, katonai, közigazgatási, kereskedelmi vagy vallási területen működött-e - vagy esetleg irodalmi műveket fordított -, nem tudjuk. Phrygiában egyébként - ókori források szerint - beszélték a kelta, pisidiai, pamphyliai, solymosi, lyd, scytha és lykaoniai nyelvet. ${ }^{12} \mathrm{Ez}$ a többnyelvűség még a késő római korban is megmaradt, sőt tovább bővült: a phrygiai Kotiaion püspöke, Selinos, apai ágon gót, anyai ágon phryg volt, ezért mindkét nyelven tudott prédikálni (Sókr. HE V, 2, 3 = PG LXVII, 648). ${ }^{13}$

Phrygia alapvetően rurális területnek számított. Nagyobb városai a déli részeken koncentrálódtak: Dionysiopolis, Hierapolis, Laodikeia, Synnada, Kolossai, Eriza, Kibyra; Sanaus, Aizanoi és Appia északon fekszik; míg középen találhatók a bizánci korban Pentapolisnak nevezett városok (Eukarpia, Hierapolis, Otrus, Bruzus, Stektorion), továbbá Akmoneia és Eumeneia. Peter Thonemann jogosan hívja fel a figyelmet arra, hogy Hierapolis (Pamukkale) és Hierapolis (Koçhisar) között hatalmas különbség volt:

Early Iron Age. Eds. N. Stampolides - C. Maner - K. Kopanias. Istanbul (2015) 211-226. Phrygiaka címen az eukarpeiai Métrophanés szofista megírta hazája történetét a Kr. u. III. században (FGrH IIIc, no. 796). Eukarpeia a Közép-Phrygiában fekvo ún. „ötváros” (Pentapolis) legfontosabb települése volt.

${ }^{8}$ Bár Gustav és Alfred Körte már 1900-ban végzett próbaásatást Gordion (Yassıhüyük) területén, a település nagy léptékű feltárására Rodney S. Young vezetésével 1950-1973 között került sor a University of Pennsylvania Museum ásatásain. A történelmi Midasról lásd S. Berndt-Ersöz: The Chronology and Historical Context of Midas. Historia 57 (2008) 1-37.

9 E. N. Merisio: Interaction between Greek and Neo-Phrygian in Bilingual Funerary Epigrams from Eastern Phrygia under the Roman Empire. In: Papers on Ancient Greek Linguistics. Proceedings of the Ninth International Colloquium on Ancient Greek Linguistics (ICAGL 9). Eds. M. Leiwo - M. Vierros - S. Dahlgren. Helsinki (2020) 157-169.

${ }_{10}$ Mitchell: i. m. (5. j.) 42-44, 170-181.

11 A. Cadwallader: Two New Inscriptions. A Correction and a Confirmed Sighting from Colossae. EA 40 (2007) 115-118.

12 Közismert eset, ami Pál apostollal történt Lystrában: „A sokaság pedig mikor látta, amit Pál cselekedett, felkiáltott, lykaoniai nyelven, mondván: Az istenek jöttek le mihozzánk emberi ábrázatban!” (Apcs 14,6). A Phrygiában beszélt nyelvekről lásd R. D. Woodard (ed.): The Cambridge Encyclopaedia of the World's Ancient Languages. Cambridge (2004) 777-788 (bibliográfiával).

${ }^{13}$ L. E. Roller: Attitudes towards the Past in Roman Phrygia: Survivals and Revivals. In: The Adventure of the Illustrious Scholar (CHANE 94). Ed. E. Simpson. Leiden (2018) 124-139. 
míg az előbbi - birodalmi mércével mérve - a közepes, az utóbbi az egészen kis városok közé tartozott. ${ }^{14} \mathrm{~A}$ magasan fekvő Phrygia klímája kontinentális-sztyeppei: akár $-20{ }^{\circ} \mathrm{C}$ alatti hideg telek és forró, száraz $\left(+30^{\circ} \mathrm{C}\right.$ feletti) nyarak jellemzik. A tengerszint felett több mint ezer méterrel elterülő phrygiai felföldön nem terem meg az olíva. A termékeny völgyekben és síkságokon árpát és búzát termesztettek, de még ennél is fontosabb volt az állattenyésztés: már Hérodotos is по入ипро $\beta \alpha \tau \omega ́$ то--nak nevezi Phrygiát $(\mathrm{V}, 49)$. A Felföld nyugati szélén, Axylon környékén élők büszkén nevezik magukat „parasztnak” ( $\varepsilon \omega \rho \gamma o ́ \varsigma)$ sírfelirataikon. ${ }^{15}$ Poliathlios sírköve is ezt bizonyítja: „Barátom, látsz egy feliratos követ; jól nézd meg, mivel ez a kő rejti Poliathliost, aki földműves volt" ( $\sigma \tau \eta ́ \lambda \eta v$

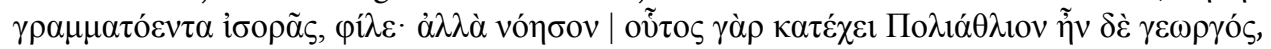
SEG I, 459 = SGO III 16/45/09, Klaneos, III. század). A földművelés jelentőségét mutatják a síremlékeken ábrázolt gabonakévék és gabonafejek. Az állattenyésztés fontosságát jelzik az ugyanitt látható szántásjelenetek, továbbá az eke, az igába fogott ökrök (vagy csak ökörfejek) ábrázolásai. Az igásállatok rendkívüli fontosságára világít rá az is, hogy az itteniek votív feliratokat állítanak $\pi \varepsilon \rho \grave{~ v a g y ~ v i ~} \pi \dot{\varepsilon} \rho \beta o \tilde{v} .{ }^{16}$ Ailianos szerint „a phrygek között halállal büntetik azt, aki megöl egy szántást végző ökröt” (De anim. XII. 34). A juhtenyésztés a Felső-Tembris-völgyben volt igen jelentős, ahol gyakran ábrázolják az állatokat, bár a pásztorokra képen és szóban is ritkábban utalnak. ${ }^{17} \mathrm{~A}$ felföld kiterjedt füves pusztáin kiváló lovakat tenyésztettek. ${ }^{18}$

\section{A phrygek ősi vallása és műveltsége}

A görög mitológiában számos történet kapcsolódik Phrygiához, ezek közül legfontosabb maga a trójai háború. Trója királyának, Priamosnak felesége, Hekuba is Dymas phrygiai király lánya volt (Hom. Il. XVI, 718), ami azért is fontos, mert így a phrygek szegről-végről a rómaiak rokonai lettek. ${ }^{19}$ Legismertebb királyaik Tantalos, Nannos,

${ }_{14}$ P. Thonemann: Phrygia: An Anarchist History, 950 BC-AD 100. In: Roman Phrygia: Culture and Society. Ed. P. Thonemann. Cambridge (2013) 1-40, kül. 32.

15 C. H. E. Haspels: The Highlands of Phrygia: Sites and Monuments. Princeton (1971) I. 311-312, no. 37; I. 314, no. 41; I. 360, no. 135.

${ }^{16}$ Waelkens: $i . m$. (6. j.) 283-284.

17 L. Robert: Hellenica: Recueil d'épigraphie, de numismatique et d'antiquités grecques. Tome VII. Paris (1949) 152-160; Waelkens: i. m. (6. j.) 286-287. Egy Damas nevű majordomusról olvassuk a szolgálólányá-

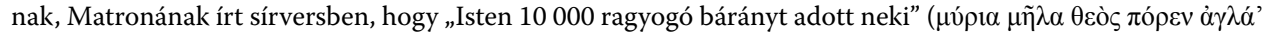

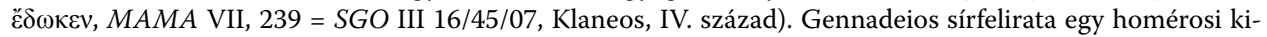

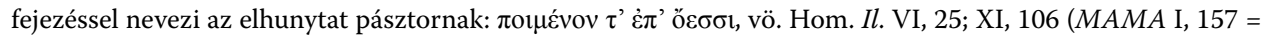
SEG VI, 343 = SGO III 14/06/03).

${ }^{18}$ J. Strubbe: A Group of Imperial States in Central Phrygia. AnSoc 6 (1975) 229-250; Waelkens: i. m. (6. j.) 287.

${ }^{19}$ A legenda szerint Aineias fia, Askanios - római nevén Iulus, a gens Iulia őse - Phrygia királya volt (Hellanikos, FGrHist I, no. 4F31; Dion. Hal. Ant. Rom. I. 47.5; I. 54.2; III. 31.4). Otrous városában legalább három olyan pénzt adtak ki, amelyen Aeneas, Anchises és Ascanius menekülése látható Trójából (U. Kelp: 
Mygdón, Gordios és Midas. Ösi istenségeik közé tartozik Kybelé istenanya, ${ }^{20}$ akit a rómaiak Magna Mater vagy Phrygia Mater néven tiszteltek. Ennek orgiasztikus jellegü

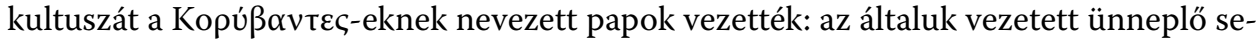
reg dobokkal, kürtökkel és sípokkal tombolva járt be hegyet-völgyet. Kybelé és hűséges társa, Attis kultuszát Kr. e. 204-ben Róma is adoptálta. ${ }^{21}$ Ugyancsak Phrygiában tisztelték Sabaziost, az Ég és az Atyaság lovon ábrázolt istenségét, akit a görögök Zeusszal azonosítottak. Zeust egyébként igen sok helyen és igen sok néven tisztelték Phrygiában: Bróntón, Limnénos, Thallos, Ampelités, Andreas, Sarendénos, Akrenénos, Erusénos, Narénos stb. ${ }^{22}$ Marijana Ricl kimutatta, hogy minden rurális szentélyközpont körül 4-5 falu helyezkedett el, egyfajta „mini-amphiktyóniát” alkotva. A rómaiak ugyancsak phryg eredetűnek tartották Mén kultuszát, akit éppen ezért phrygiai sapkában is ábrázoltak, amint épp lovagol, jogarral vagy dárdával a kezében. Mén egyébként valószínűleg perzsa eredetű holdisten, akit a pisidiai Antiochiában és Pontusban is kultiváltak. ${ }^{23}$ Anatóliában főként a nagy templomi birtokokon és a hozzájuk tartozó falvakban tisztelték mint termékenységadó istent, illetve a sírok őrzőjét (vö. Strabón XII, 3, 31 C 556). A körülbelül 370 fennmaradt és neki címzett dedikációban egyebek mellett Tyrannos, Uranios és Megas jelzőkkel illették. ${ }^{24}$ A különleges nevű Bas tisztelete csak phryg feliratokon mutatható ki, görög szövegekben nem is említik. ${ }^{25}$

Hogy a phrygek népét, nyelvét és kultúráját mennyire ősinek tartották maguk a görögök is, mutatja a Hérodotosnál megőrzött történet (II, 2). Eszerint Psammétichos fáraó (I. Psamtik, Kr. e. 664-610) szerette volna megtudni, mi az emberiség legősibb, eredeti nyelve, ezért két csecsemőt elzártan neveltek fel, úgy, hogy emberi szót nem hallottak. Amikor az egyik először megszólalt, a bekos szót ejtette ki, ami phrygiai nyelven kenyeret jelent. Ezért az egyiptomiak is őket tartották a legősibb népnek. ${ }^{26}$ Phrygia híres volt kultúrájáról: a görög hagyomány a trójai háború előtt élt Orpheust - a költé-

Grabdenkmal und lokale Identität. Ein Bild der Landschaft Phrygien in der römischen Kaiserzeit. Bonn (2015) 89. no. 42). A phrygek paradox megítéléséről Rómában lásd P. Hardie: Phrygians in Rome/Romans in Phrygia. In: Tra Oriente e Occidente: indigeni, Greci e Romani in Asia Minore. Ed. G. Urso. Pisa (2007) 93-103.

${ }^{20} \mathrm{Az}$ istenség neve egész bizonyosan a hettita Kubaba $(K u-b a-b a, K u-p a-p a)$ névre vezethető vissza. Érdekes, hogy a hettita Birodalom fennállása idején (kb. Kr. e. 1400-1190) csak kisebb szerepet játszott a mitológiában, Hattusa bukása után az ún. „neo-hettita államok” fő istensége lett Kilikiától a Halys folyóig, lásd J. D. Hawkins: Kubaba at Karkamiš and Elsewhere. AS 31 (1981) 147-176.

${ }^{21}$ A Kybelé-kultuszról lásd L. E. Roller: In Search of God the Mother: The Cult of Anatolian Cybele. Berkeley - Los Angeles (1999); Attis kultuszáról lásd J. Bremmer: Attis: A Greek God in Anatolian Pessinous and Catullan Rome. Mnemosyne 57 (2004) 534-573.

${ }^{22}$ M. Ricl: Society and Economy of Rural Sanctuaries in Roman Lydia and Phrygia. EA 35 (2003) 77-101; H. Güney: The Sanctuary of Zeus Sarnendenos and the Cult of Zeus in Northeastern Phrygia. AS 69 (2019) 155-174.

${ }^{23}$ G. Labarre: Les origines et la diffusion du culte de Men. In: L'Asie mineure dans l'Antiquité: Échanges, populations et territoires. Eds. H. Bru - F. Kirbihler - S. Lebreton. Rennes (2009) 389-414.

${ }^{24}$ E. N. Lane: Corpus monumentorum religionis dei Menis (CMRDM), vols. I-II. Leiden (1971-1978).

25 B. Obrador-Cursach: The Phrygian God Bas. JNES 76 (2017) 307-317.

26 A római kori szerzők számára ez már közhely: Paus. I, 14, 2; Arr. FGrHist 156 F 82; Apul. Met. XI, 5; Hipp. Adv. Haer. V, 7; Orig. C. Cels. IV, 36; Claud. In Eutrop. II, 238-273. 
szet primus inventorát - tartotta Midas tanítómesterének, és a phrygek nemcsak saját zeneszerszámokat ( $\alpha$ $\lambda$ ó $\varsigma$ = „nádnyelves kettős síp” - ennek feltalálója a szerencsétlenül járt Marsyas volt), hanem a görög zene egy saját módját, a fríg modális hangsort is kifejlesztették, amit harcias hangzásúnak véltek. ${ }^{27} \mathrm{~A}$ legősibb phrygiai verset Thymoitésnak, a trójai Laomedón unokájának tulajdonították (Diod. Sic. III, 67, 5). Cicero a De natura deorum című művében rezonőrjével, Cottával mondatja ki, hogy a mitológia nem is egy Herculest ismer. Az egyik közülük az egyiptomi, a Nílusból jött elő, „akiről azt mondják, hogy ő állította össze a phrygiai szent könyveket" (quem aiunt Phrygias litteras conscripsisse, De nat. III, 16, [42], Havas László fordítása). Hasonló utalás olvasható Plutarchosnál is (De Is. et Os. 29, 362b). De vajon mire utalnak ezek a Herculessel, illetve Egyiptommal is kapcsolatba hozott, titokzatos „könyvek” (litterae, $\gamma \rho \alpha ́ \mu \mu \alpha \tau \alpha)$ ? James Rives szerint a görögöknél elterjedt nézet volt, hogy a perzsa mágusok, az egyiptomi papok, valamint a saját orphikus írásaik mellett a phrygek titokzatos „könyvei” valamiféle ősi tudást őriznek az istenekről. ${ }^{28} \mathrm{Az}$ athéni Diagoras volt a szerzője egy bizonyos Phrygiai mesék (Phrygioi logoi) címü műnek, de ugyanilyen maradt fenn Démokritos neve alatt is. ${ }^{29}$ Ha Rivesnek igaza van, akkor ezek valamiféle euhémerisztikus mitológiai kompilációk (például genealógiák) lehettek.

\section{A phrygiai síremlékek sajátosságai}

A Római Birodalom területén élő népek körében az identitás egyik fontos kifejezési módja volt a temetkezés, melynek ezerféle módja ismert a germaniai Iuppiter-oszlopoktól a palmyrai toronysírokon keresztül a jellegzetes pun sírsztélékig. Phrygiában is a bronzkor óta folyamatosan tovább élő temetkezési formákat figyelhetünk meg.

\subsection{Síremléktípusok}

A sziklába vágott, impozáns homlokzattal díszített, belül bútorozott sírboltokat a Kybelé-kultusszal hozta összefüggésbe a kutatás - a Nagy Istenanya oroszlánjai még a római kori sírok tympanonjaiban is gyakran feltünnek. ${ }^{30} \mathrm{~A}$ római korban azonban már

27 A phrygiai találmányokról: E. N. Andreeva: Phrygian Inventions by Pliny the Elder. Шагu / Steps 6 (2020) 57-72. A phryg dallam megítéléséről: B. Levick: In the Phrygian Mode. A Region Seen from Without. In: Roman Phrygia: Culture and Society. Ed. P. Thonemann. Cambridge (2013) 41-54, kül. 41-44.

${ }_{28}$ J. B. Rives: Phrygian Tales. GRBS 45 (2005) 223-244. Erre utal még Plut. De def. orac. 10, 415A és De Daed. Plat. F 157 Sandbach (= Eus. Praep. Evang. III, 1, 1).

${ }_{29}$ Tat. Ad Graec. 27. = Diagoras T 68 ed. Winiarczyk. - Diog. Laert. IX, 49 (vö. Democritus D.-K. 68 B 299a-h).

${ }^{30}$ A sziklába vágott sírokról: S. Berndt-Ersöz: Phrygian Rock-Cut Shrines. Structure, Function, and Cult Practice. Leiden (2006); a kapu-sírokról: M. Waelkens: Die kleinasiatischen Türsteine. Typologische und epigraphische Untersuchungen der kleinasiatischen Grabreliefs mit Scheintür. Mainz (1986); általában a temetkezésekről: T. Lochman: Studien zu kaiserzeitlichen Grab- und Votivreliefs aus Phrygien. Basel (2003); U. Kelp: Grave Monuments and Local Identities in Roman Phrygia. In: Roman Phrygia. Culture and Society. Ed. P. Thonemann. Cambridge (2013) 70-94. 
az épített síremlékek és a különálló sírsztélék voltak a legjellemzőbbek, azon belül is két típus a leggyakoribb: a síroltároké $(\beta \omega \mu$ ó $\varsigma)$ és az ún. kapu-síroké $(\theta u ́ \rho \alpha)$; természetesen ezek mellé sorolhatjuk a gazdagabbak temetkezési helyéül szolgáló szarko-

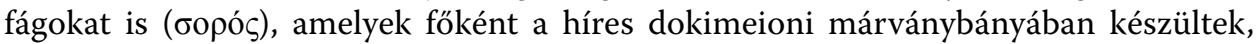
és természetesen a városi elitréteg körében voltak használatosak. Nyugat-Phrygiában már a Kr. u. I. századtól a síremlékek sokfélesége jelenik meg, míg Kelet-Phrygiában csak a II-III. században tünnek fel tömegesen elsősorban a kapu-sírok. Léteznek helyi jellegzetességek is: a fenyőtobozban végződő sírsztélék például Akmoneia környékén gyakoriak. A sírok domborművein - ahogy fentebb is láthattuk - rendkívül gyakoriak a mindennapi életből vett ábrázolások, amelyek az elhunytak foglalkozására, társadalmi státuszára és nemére utalnak. Érdekes módon ezek a reliefek sokkal gyakoribbak a rurális területeken (például Felső-Tembris-völgy), mint a városok (például Aizanoi, Philomelion) környékén.

\subsection{Táblák és tekercsek ábrázolásai ${ }^{31}$}

A római kori Phrygiában fellelhető valamennyi síremléktípuson igen gyakran találunk írószereket (stylus és tolltartó) és íróanyagokat (tekercsek, írótáblák) ábrázoló dombormüveket. A síroltárok (bómoi), sírsztélék (tymbos, séma) és a kapu alakú sírkövek (thyra) egyaránt tartalmaznak ilyeneket, ritkábban önálló motívumként, gyakrabban más dolgokkal együtt: mint például a kulcslyuk és ajtópánt (kapu-sírköveken), oroszlán, sas, ökörfej, szántó ökrök, juhok, tengeri állatok, gyümölcsös kosár, különféle háztartási és kozmetikai eszközök (tükör, fésü, alabástromampulla, gyapjúkosár, tủ, guzsaly, orsó), szőlő, virág, amphora stb. A sírábrázolások motívumainak gyakorisága területenként változó: például Aezani környékén igen kevés az írótáblát és/vagy tekercset ábrázoló dombormü, és az is egyértelműen a paideiához, vagyis a gyermekek képzéséhez kötődik. ${ }^{32}$ A hagyományos értelmezés szerint a férfiak világát jellemzik a mezőgazdasági eszközök és munkálatok (metszőkés, eke, szántás), valamint az állatok képei mellett az íróeszközök; míg a nők világához a gyapjúfonással, valamint a szépítkezéssel kapcsolatos tárgyak tartoznak. Ez a párhuzam a negotium/otium szembeállításnak is megfelel. ${ }^{33}$ Ugyanakkor ennek némileg ellentmond, hogy az íróeszközöket a kizárólag nők számára

31 A „Tekercs a kézben - Kísérlet a római sírábrázolások egyik gyakori ikonográfiai motívumának értelmezésére" címen 2020-ban indult OTKA-kutatás (NKFI K 135317) célja a Római Birodalom területén fellelhető sírdomborművek íróanyag-ábrázolásainak összegyűjtése és értelmezése. A kutatócsoport vezetője Prof. Dr. Grüll Tibor tanszékvezető egyetemi tanár (PTE BTK TTI Ókortörténeti Tanszék); tagjai: Dr. Jusztinger János tanszékvezető egyetemi adjunktus (PTE ÁJK Római Jogi Tanszék); Dr. Agócs Nándor egyetemi adjunktus (ELTE BDPK Történelem Tanszék); Szabó Ernő doktorjelölt, tudományos segédmunkatárs (PTE BTK Interdiszciplináris Doktori Iskola; Ókortörténeti Tanszék).

32 Például MAMA IX, p. 134. no. 424 tolltartó; p. 150-151. no. 477. Ugyanezt látjuk a 8 évesen elhunyt Gennadios síremlékén Appiában, ahol a háromszög alakú akrotérionban nyitott tekercs, tolltartó és diptychon szerepel (SGO III 16/31/77).

${ }^{33}$ Lochman: i. m. (30. j.) 190-192; T. Wujewski: Anatolian Sepulchral Stelae in Roman Times. Poznań (1991) 20-25; J. Masséglia: Phrygians in Relief: Trends in Self-representation. In: Roman Phrygia. Culture and Society. Ed. P. Thonemann. Cambridge (2013) 95-123, kül. 99-101. 
emelt sírsztéléken is megtaláljuk; továbbá ezek az eszközök nemcsak a pogány, hanem a keresztény sírokon is láthatók, ahol akár egészen más - vallási - konnotációjuk is lehet. ${ }^{34}$ A teljesség igénye nélkül, inkább csak egy-egy jellemző példával felsorolom a phrygiai síremlékeken látható íróanyag- és íróeszköztípusokat: zárt tekercsek, olykor sillybosszal, vagyis a tekercsekhez ragasztott címkével (például $M A M A$ I, p. 27. no. 41, p. 62. no. 115); félig nyitott tekercsek sillybosszal (például $M A M A$ VI, p. 104. no. 288; p. 104. no. 289); tolltartó nyitott tekerccsel és két zárt tekercs között (például $M A M A \mathrm{~V}$, p. 25. no. 41); tolltartó önálló motívumként (például $M A M A$ IV, p. 6. no. 16, p. 10. no. 31; MAMA VI, p. 106. no. 300).

Érdekes, hogy a Duna menti provinciákban igen gyakori - de az egész Római Birodalomban előforduló - ikonográfiai motívum: a bal kézben tartott zárt tekercs itt igen ritka. ${ }^{35}$ Egy különleges ház alakú síremléken egymás mellett látható a nyitott tekercs, a tolltartó és az írótáblák ( $M A M A$ V, p. 28. no. 48); vagy egy másik kőemlék tympanonjában egymás mellett egy ló, egy nyitott papirusztekercs, egy tolltartó, egy stylus, alatta írótáblák és egy férfi mellszobor ( $M A M A$ IV, p. 78-79. no. 216). Az írótáblák egyébként sokkal gyakoribb motívumnak tünnek, mint a tekercsek. Látunk zárt polyptichont csillag alakú kapoccsal (MAMA VI, p. 106. no. 300; MAMA VI, p. 108. no. 309); nyitott diptychont (MAMA IV, p. 8. no. 22); stylust nyitott diptychonnal (MAMA VI, p. 100. no. 275); zárt diptychont ( $M A M A$ V, p. 89. no. 189). A jellegzetesen phrygiai kapu-sírokon $(\theta u ́ p \alpha)$ is megtaláljuk az íróanyagokat. Az általában négyosztatú kapuszárnyakon a jobb felső szelvényében egy kulcslyuk, a bal felsőben pedig egy zsanér látható, az alsó szelvényekben pedig a szokott motívumok. ${ }^{36}$

De vannak ettől eltérő minták is: például a jobb felső szelvényben nyitott papirusztekercs, tolltartó, diptychon, a bal alsóban tükör, nyitott tekercs és láda, a jobb alsóban olvasóállvány és zárt tekercs ( $M A M A$ V, p. 21-24. no. 40); a bal felsőben nyitott tekercs, a jobb felsőben capsa (MAMA V, p. 26, no. 43); a jobb felsőben kulcslyuk, a bal felső-

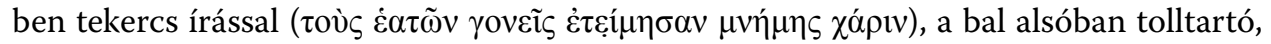
a jobb alsóban kosár és guzsaly (MAMA VI, p. 103. no. 285); a bal alsóban diptychon (MAMA VI, p. 112-113. no. 322); a bal alsóban két tolltartó, a jobb alsóban nyitott

${ }^{34}$ Lásd például Eutropios sírját a 6.1.2. fejezetben, ahol a bómos oldalán egy nyitott tekercset ábrázoltak, ami akár a Szentírásra történő utalás is lehet. Ugyanakkor Eurélios Eutychos sírján, amely kifejezetten keresztény, szintén megtaláljuk a szokott szántóvető ökrök, ló, valamint a diptychon, tolltartó és félig nyitott tekercs motívumokat, lásd E. Gibson: The 'Christians for Christians' Inscriptions of Phrygia. Greek Texts, Translation and Commentary (HThS 32). Missoula (1978) 12-14. no. 3.

35 Zárt tekercs a férfi jobb kezében: $M A M A$ IV, p. 90. no. 247; zárt tekercs a férfi bal kezében: $M A M A$ VI, p. 138. no. 405; SEG XXVIII, 1105 = SGO III 16/31/03 (Ammia és fia, Nikanór sírfelirata, korrekt hexameter, de nem szerepel benne utalás az elhunyt személyek műveltségére); IGR IV, 608 = SEG VI, $166=M A M A$ X, no. 137 = SGO III 16/31/08 (egy 25 évesen elhunyt építész, kezében tekerccsel, lábánál egy tolltartóval, aki

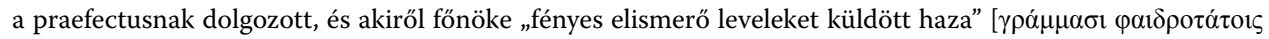

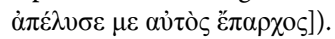

${ }^{36}$ A női szépítkezés kellékei (tükör, fésű, illatszeres fiola stb.), de időnként más motívumok is felbukkannak: például Héraklés és a Kerberos (SEG XXVIII, 1091; Waelkens: $i$. m. (30. j.) no. 233; SGO III $16 / 31 / 02)$. 


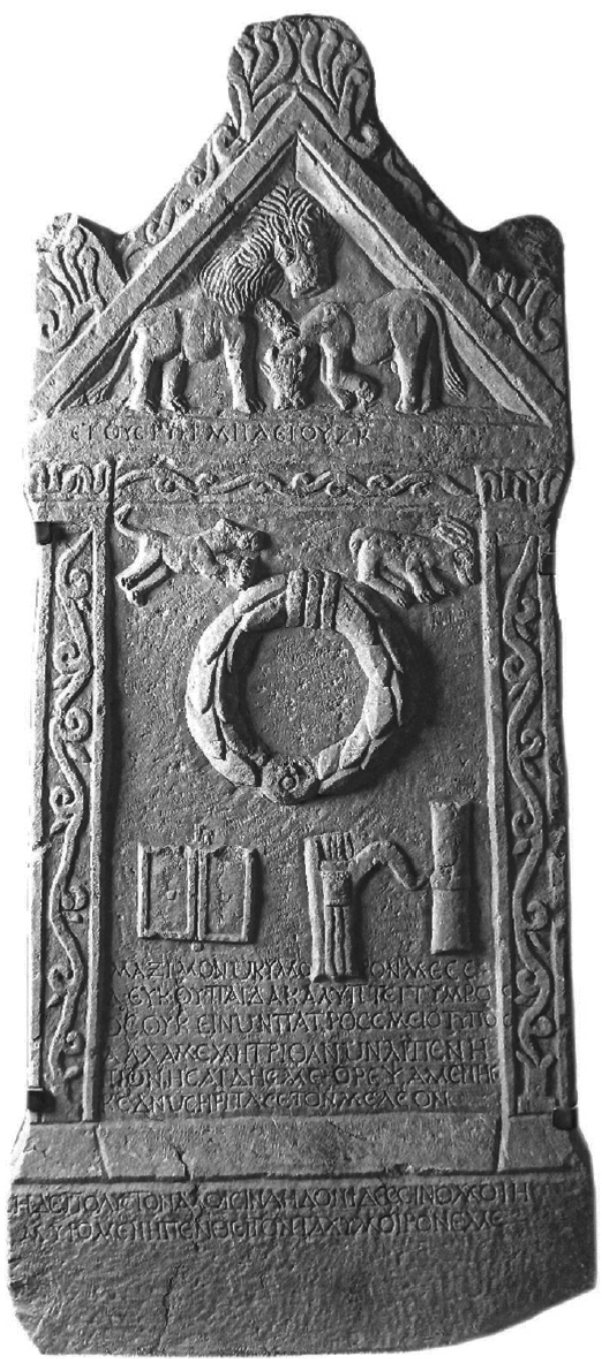

1. ábra. Íróeszközök Maximos síremlékén, lelőhelye ismeretlen, Kr. u. 167, Uşak Arkeoloji Müzesi (Şenkal Kileci: A New Epigram in the Ușak Museum: The Relief Stele of Maximus. Gephyra 20 [2020] 143.)

tekercs (MAMA VII, p. 62. no. 279) stb. Alkalmanként a kapu-sírok akrotérionjában látható diptychon, kosár vagy capsa és nyitott tekercs cédulával ( $M A M A \mathrm{~V}, \mathrm{p}$. 78. no. 167); esetleg fésü, tükör, nyitott tekercs és tolltartó ( $M A M A$ VI, p. 102. no. 279). A sírfeliratok és az ábrázolások között csak ritkán találhatunk szoros összefüggést. Erre példa a 18 évesen elhunyt Severa felirata, akinek testvére, Clemens állított síremléket (Teme- 


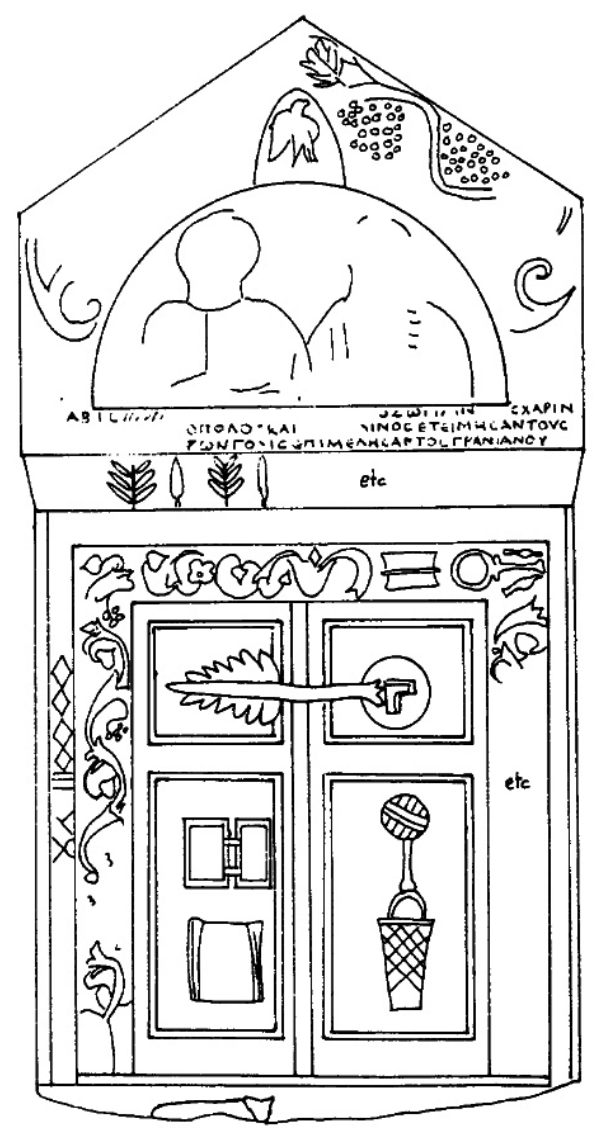

2. ábra. Íróeszközök kapu-síron, Cotiaeum, Ortaca helységből (Monumenta Asiae Minoris Antiqua vol. X. Eds. B. Levick - S. Mitchell - J. Potter - M. Waelkens. London [1993] 100, no. 312.)

nuthyrai, II. század vége, III. század eleje). ${ }^{37}$ Ezen két boltíves kapu látható, a bal oldali ajtószárnyon középen egy nagy tükör, tőle balra egy kis korsó, tőle jobbra pedig egy fésű; míg a jobb oldali ajtószárnyon felül egy nyitott írótábla (diptychon), alul pedig egy nyitott tekercs (volumen). Úgy tünik, a metrikus sírfelirat itt közvetlen kapcsolatban áll az ábrázolásokkal, mivel a szöveg az elhunyt lány szépségét és „tiszteletre méltó karakterét" dicséri:

37 E. Gibson: Montanist Epitaphs at Ușak. GRBS 16 (1975) 433-442, no. 4; T. Drew-Bear: The City of Temenouthyrai in Phrygia. Chiron 9 (1979) 275-302, kül. 299-301; Waelkens: i. m. (30. j.) 148-149, no. 371; SGO III 16/08/04. 


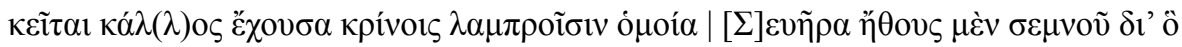

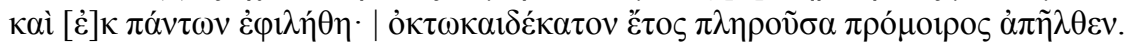

Itt nyugszik ragyogó liliomokhoz hasonló szépségü | Severa, tiszteletre méltó jellemü, amiért mindenki szerette. | Tizennyolc évet betöltve idő előtt ment el.

Elsa Gibson szerint „Severa józan, egyenes jellemű, amihez jól illik a neve, amint arra a

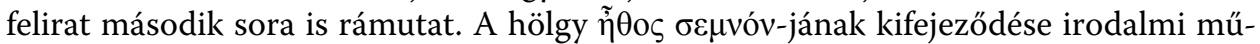
veltsége (literacy), amelyre síremlékének jobb ajtószárnya vonatkozik: megfigyelhető, hogy az írás- és olvasási képességére külön-külön utalnak, az előbbire a viasztáblákkal, az utóbbira egy tekerccsel. Severa szépsége, amiről az első sor beszél, a bal ajtószárnyon van illusztrálva: tükör, parfümös üvegcse és egy fésü.” Egy 13 évesen elhunyt fiúnak, Gaianosnak szülei állították azt a síremléket Dorylaionban, amelyen a gyermek viasztáblákra írt saját verséből idéztek: ${ }^{38}$

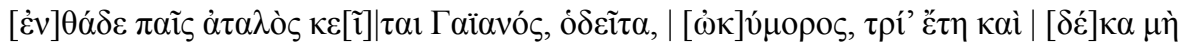

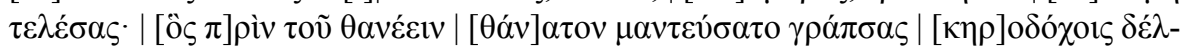

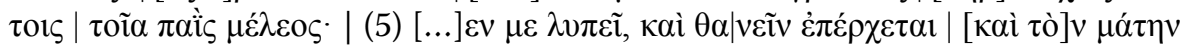

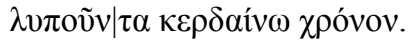

Vándor, itt nyugszik egy fiatal gyermek, Gaianos, | korai halálra kárhoztatott, aki 13. évét sem töltötte be, | aki mielőtt meghalt volna, megjósolta ezt írván | viasszal bevont táblákra, a szerencsétlen gyermek: | (5) »semmi sem bánt engem, a halál közeleg, | és megspórolom a hiábavaló szomorúsággal [töltött] időt«.

Ez a sírfelirat egyrészt közvetlen utalás arra, hogy a síremlékeken ábrázolt írótáblákat a valóságban is széles körben használták, másrészt azok a könyves műveltségen túlmenően akár az elhunyt költői (Thonemann szerint csupán „versfaragói”) képességeire is utalhatnak.

\subsection{A vallási identitás kifejezése}

A epigráfiai emlékeken a feliratok állítóinak vallási identitása sokféle módon fejeződik ki. ${ }^{39}$ Mindenekelőtt az istenség neve, akinek az oltárt vagy votívumot állították, illetve akit az epitáfiumban magasztaltak / segítségül hívtak, legtöbbször elárulja, hogy az illető melyik vallás követője. Azután itt vannak a Phrygiában különösen nagy számban előforduló átokformulák, amelyek a sírrongálókra és sírrablókra kérnek átkot bizonyos istenségektől. (Persze olyan is akadt, aki az egyszerüség kedvéért a „legyen átko-

${ }^{38}$ R. Oberhummer - H. Zimmerer: Durch Syrien und Kleinasien: Reiseschilderungen und Studien. Berlin (1899) 381-382, no. 3; SGO III 16/34/26.

${ }^{39}$ Mitchell: $i . m$. (5. j.) 187-195. 
zott az összes istentől” formulát használta.) A görög, római és lokális istenségek hívei sokszor képi formában is ábrázolták az általuk tisztelt istenalakokat, míg a zsidók és keresztények csupán szimbólumokkal (menóra; christogram stb.) utaltak vallási identitásukra.

\subsubsection{Pogány feliratokon}

A 3. pontban már esett szó Zeus, Kybelé, Attis, Sabazios és Mén kultuszáról, amely őshonosnak tekinthető a phrygek körében. A vallási identitás legfontosabb eleme a különféle istenségekhez „tartozás”, amit imákkal, votív ajándékokkal és áldozatokkal fejeztek ki a hívők. Megszokott, hogy a sírfeliratok szövegeiben - Plutón/Hádés és a Moirák emlegetése mellett - a „klasszikus” istenségeket is invokálják. Az appiai Grapté így szólal meg: „akit te, Kypris istennő, együtt kedves apáddal és a Charisokkal segíts

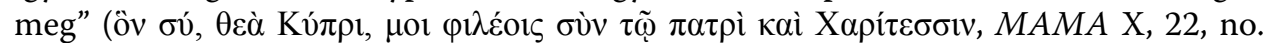
75 = SGO III 16/31/86); Aphrodité egyébként Homérosnál Zeus és Dióné lányaként szerepel (például $I l$. IV, 128). Phrygiában egy egészen sajátos felirattípus is keletkezett a Kr. u. II-III. században, amit „bűnbánati” vagy „kiengesztelő” feliratoknak nevezünk (confession/propiatory inscriptions). ${ }^{40}$ Ezeket Mén (Axiottenos, Artemidóros), Métér, Zeus (Aithrios, Keraunios, Sótér), Apollón, Hypsistos, Anaitis, Attis, Dionysos, Hadés, Héraklés, Sabazios, Batenos, Nemesis, Asklépios, Tyrannos, Basileus, Theos Straptón és/vagy Brontón, Hekaté és Artemis tiszteletére állították fel, akiket „hazai istenségek-

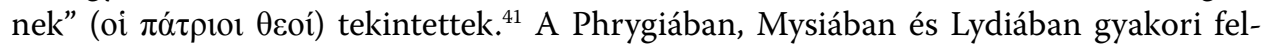
iratok azonos sémára épülnek: az illető megnevezi magát; bevallja bűnét, ami kiváltotta az istenség haragját; leírja a büntetést, amit bűnéért szenvedett; elismeri az istenség hatalmát; az istenség parancsára felállít egy sztélét; majd megígéri, ettől kezdve nem lesz hitetlen, és tisztelni fogja az adott istenséget. ${ }^{42}$ Kevés kivételtől eltekintve a kutatás nem foglalkozott azzal, hogy a II-III. század a kereszténység látványos és erőteljes előretörésének az időszaka, és ezekben a pogány konfessziós feliratokon az újszövetségi termi-

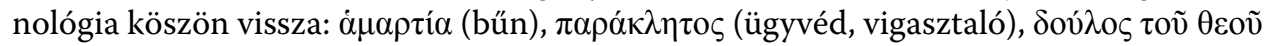

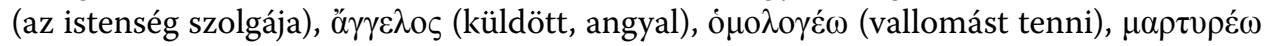

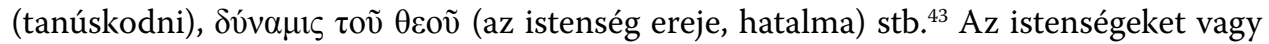

40 Kiadásuk: G. Petzl: Die Beichtinschriften Westkleinasiens (Epigraphica Anatolica 22). Bonn (1994).

${ }^{41}$ Ezeket az istenneveket még különféle jelzőkkel - „Legmagasabb, Legnagyobb, Legjobb” stb. - látták el, lásd C. Marek: Der höchste, beste, größte, allmächtige Gott. Inschriften aus Nordkleinasien. EA 32 (2000) 129-146.

42 A feliratok narratív szerkezetéről lásd A. Rostad: Confession or Reconciliation? The Narrative Structure of the Lydian and Phrygian 'Confession Inscriptions'. SymbOsl 77 (2002) 145-164; vallástörténeti értékelésükről: J. Vikman: Little Big Gods: Morality of the Supernatural in Lydian and Phrygian Confession Inscriptions. In: Walking Together and Parting Ways: Religious Identities in Antiquity and Late Antiquity. Eds. I. Lindstedt - N. Nikki - R. Tuori. Leiden (2021).

${ }^{43}$ E. Schnabel: Divine Tyranny and Public Humiliation: A Suggestion for the Interpretation of the Lydian and Phrygian Confession Inscriptions. NT 45 (2003) 160-188. 
antropomorf módon, vagy szimbólumokkal (Mén = félhold) jelzik, hatalmukat pedig a „jogar” ( $\sigma \kappa \tilde{\eta} \pi \tau \rho o v)$ kifejezés demonstrálja, amit vagy az istenség, vagy annak papja tart. A Phrygiában megtalálható kultuszok kölcsönös egymásra hatását mutatja a „Legma-

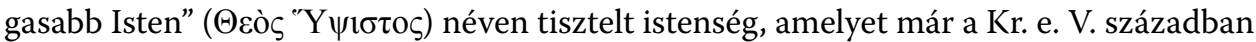
Zeusra is értettek, majd a Septuagintában - a héber Él Eljón fordításaként - és az Újszövetségben is a zsidók és a keresztények Istenére használták, ${ }^{44}$ ahonnan a diaszpórai zsidók által állított feliratokon is elterjedt, majd ennek visszahatásaként a pogányok is

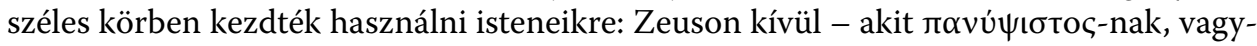
is „mindenek felett legmagasabbnak” is neveztek - Héliosra, Poseidónra, Apollónra, Ménre, Kybelére, Attisra, Isisre, Sarapisra és Mithrasra is alkalmazták. ${ }^{45}$ Hasonló jelenség figyelhető meg az ún. „eumeneiai átokformula” használatával kapcsolatban is (szin-

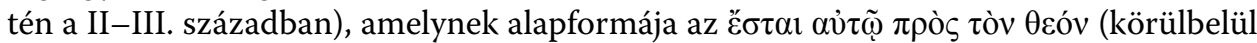
„legyen elszámolnivalója istennel”) bizonyosan bibliai eredetű, de a zsidók, keresztények és pogányok saját vallási elképzeléseik szerint alakították tovább. ${ }^{46}$ Végül itt kell megemlékeznünk egy különleges elvont istenségről, amelynek szinkretisztikus kultu-

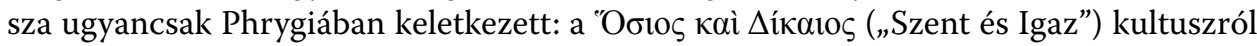

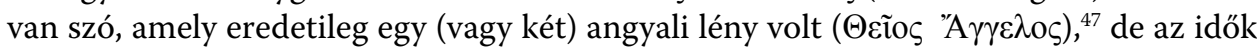
során különféle pogány istenségekkel azonosították, és még sajátos ikonográfiája is kialakult (lovas istenség). ${ }^{48}$ Elég valószínü, hogy a Kol 2,18-ban Pál apostol által említett

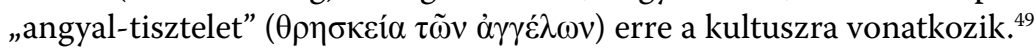

${ }^{44}$ A judaizmusban: Y. Ustinova: Theos Hypsistos and Judaism. In: The Supreme Gods of the Bosporan Kingdom. Celestial Aphrodite and the Most High God (RGRW 135). Leiden (1999) 203-239; az Újszövetségben: P. R. Trebilco: Paul and Silas - 'Servants of the Most High God' (Acts 16.16-18). JSNT 11 (1989) 51-73. A kifejezést mint a zsidó monoteizmus „kulturális transzlációját” értelmezi J. Lanckau: Hypsistos: Cultural Translation of Jewish Monotheism in the Hellenistic Period. AS/ES 65 (2011) 861-882.

45 S. Mitchell: The Cult of Theos Hypsistos between Pagans, Jews, and Christians. In: Pagan Monotheism in Late Antiquity. Eds. P. Athanassiadi - M. Frede. Oxford (1999) 81-148; N. Belayche: Hypsistos: A Way of Exalting the Gods in Graeco-Roman Polytheism. In: The Religious History of the Roman Empire. Pagans, Jews and Christians. Eds. J. A. North - S. R. F. Price. Oxford (2011) 139-174.

${ }^{46}$ P. R. Trebilco: The Christian and Jewish Eumeneian Formula. In: Negotiating Diaspora: Jewish Strategies in the Roman Empire. Ed. J. M. G. Barclay. London (2004) 66-88. Nyilvánvaló, hogy a „legyen elszámolnivalója J(ézus) K(risztussal)” vagy a „Szentháromsággal” keresztény; a „legyen elszámolnivalója Héliosszal és Selénével” pedig pogány formula. Viszont számos alkalommal nem lehet eldönteni, hová is sorolható: például „legyen elszámolnivalója az istenség hatalmas erejével” vagy a „számoljon el az ítéletkor” kifejezések esetében, hacsak a feliraton szereplő név vagy egy szimbólum nem segít az azonosításban.

47 A. R. R. Sheppard: Pagan Cults of Angels in Roman Asia Minor. Talanta 12 (1980) 77-101. A szerző szerint a kultusz zsidó eredetű, ami nem kizárt, tekintve, hogy a kifejezés gyakori a LXX-ban.

${ }^{48}$ A kultuszhoz tartozó feliratokat Marijana Ricl jelentette meg 1991-2008 között, lásd még H. Güney: New Inscriptions from Northeast Phrygia: The Cult of Hosios and Dikaios. Gephyra 15 (2018) 101-117. A Hosios és a Dikaios - emberre és Istenre egyaránt vonatkoztatva - számtalanszor megtalálható a Bibliában is egymás mellett: például 5Móz 32,4; Ef 4,24; Tit 1,8; Jel 16,5 stb., ugyanakkor a pogány irodalomban is szerepel.

${ }^{49}$ C. E. Arnold: The Colossian Syncretism: The Interface between Christianity and Folk Belief at Colossae (WUNT II. 77). Tübingen (1995). 


\subsubsection{Zsidó feliratokon}

Phrygiában 13 helységből összesen 47 zsidó felirat került elő, ami viszonylag jelentős szám. ${ }^{50}$ A phrygiai zsidó közösség letelepítése III. Antiochos Theos idejére nyúlik vissza (Jos. Ant. XII. 3.4. [147]), és az itteni zsidók szerepelnek a jeruzsálemi „első pünkösd” felsorolásában is (Acta 2,10). ${ }^{51}$ A Talmud szerint a tannák második generációjához tartozó Rabbi Eleazar ben Arach a Kr. u. I. században látogatta meg az itteni diaszpórát, amely bortermeléséről volt híres (b.Sabb. 147b). Egy phrygiai származású ( Sambatis (másnéven Athénais) névre hallgató zsidó rabszolganőt Alexandriában vásároltak meg Kr. u. 151-ben (BGU III 887 = CPJ III 490). Az itteni zsidó feliratokra jellemző, hogy bár a nevek többsége már asszimilált görög elnevezés (azért akad néhány kivétel is, például Sámuel, Jákób, Júda, Debóra), a sírfeliratokon többnyire nyíltan

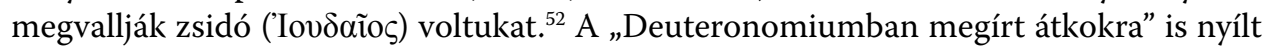
utalásokat tesznek (nos. 172-174, 213); de kétszer előfordul az „átok sarlója” kifejezés is, amely a Zak 5,1-4 LXX-fordítására vezethető vissza (nos. 175, 176). Akmoneiában arra hivatkoznak a feliratok átokformuláiban, hogy az olvasó „ismeri a zsidók törvényét”

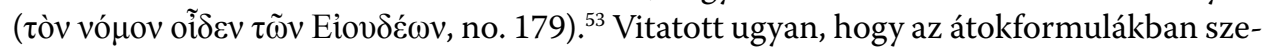

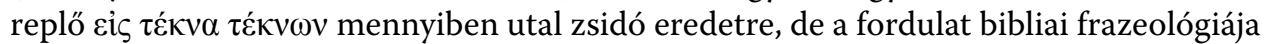
egyértelmű (például 2Móz 34,6-7).54 A zsinagógákra is történik utalás Akmoneiában (no. 168) - ahol egy menórával díszített ión oszlopfő is előkerült ${ }^{55}$-, és Hierapolisban (no. 191). Egy magát rabbinak nevező archisynagógos is szerepel Dokimeionban (no. 184), továbbá találunk egy archisynagógost Syannadában is (no. 214). Hierapolisban olyan jelentős zsidó közösség élt, hogy az egyik szarkofágfeliraton megemlítik a „zsidók

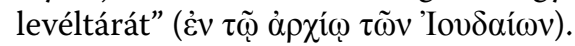

50 IJO II pp. 342-448, nos. 167-214 (Aizanoi, Akmoneia, Amorion, Apameia, Appia, Diokleia, Dokimeion, Dorylaion, Eumeneia, Hierapolis, Kotiaeion, Laodikeia/Lykos, Synnada).

51 A. Schalit: The Letter of Antiochus III to Zeuxis Regarding the Establishment of Jewish Military Colonies in Phrygia and Lydia. JQR 50 (1960) 289-318; P. van der Horst: The Jews of Ancient Phrygia. EJJS 2 (2008) 283-292.

52 Például Aurelius Alexandros (no. 182); Artemón (no. 188); Iasón (no. 190); Apphias és Iulianos (no. 191); Tatianos (no. 192); Tryphón (no. 194) stb.

${ }^{53}$ Az átokformulákhoz: J. Strubbe: APAI EПITYMBIOI. Imprecations against Desecrators of the Grave in the Greek Epitaphs of Asia Minor: A Catalogue (Die Inschriften griechischer Städte aus Kleinasien 52) Bonn (1997); P. R. Trebilco: Jewish Communities in Asia Minor. Cambridge (1991) 60-69. Az erre hivatkozó feliratok kivétel nélkül a Kr. u. III. század közepén, vagyis a Severusok kora után keletkeztek, amikor a zsidók számára jelentős könnyítéseket vezettek be, például beengedték őket az állami hivatalokba. Trebilco amellett érvel, hogy a formula egyaránt szólhatott zsidóknak és pogányoknak, mivel ez utóbbiak is ismerték a zsidók szent könyvének „mágikus erejét”. Erre példa, hogy az euboiai Chalkisban a nem zsidó T. Flavius Amphikles által a Kr. u. II. század közepén állított felirat tételesen fel is sorolja az 5Móz 28,22 átkait, lásd C. P. Jones: Prosopographical Notes on the Second Sophistic. GRBS 21 (1980) 373-380, kül. 377-378.

54 Trebilco: $i . m$. (53. j.) 69-74.

55 A nevezetes zsinagógát Iulia Severa alapította, aki Nero idejében a város főpapnője volt, és az Akmoneiában kiadott pénzeken és feliratokon is sürűn előfordul, lásd Trebilco: $i$. m. (53. j.) 58-60. 


\subsubsection{Keresztény feliratokon}

A phrygiai epigráfia egyik legkülönlegesebb vonását a Konstantin előttről datálódó keresztény feliratok nagy száma jelenti. ${ }^{56} \mathrm{~A}$ római katakombákon kívül nincs egyetlen más hely sem a Római Birodalomban, ahonnan ennyi korai keresztény feliratot ismernénk ráadásul ezek nem föld alatti kazamatákban, hanem nyilvános temetőkből kerültek elő. ${ }^{57}$ A társadalom minden rétegéből származó keresztények feliratai - csakúgy, mint a zsidók esetében - a sajátos nevekről, bizonyos szimbólumokról (kereszt vagy christogram),

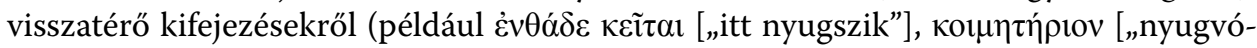
hely”], $\dot{\alpha} \delta \varepsilon \lambda \varphi o i ́$ [„testvérek”], $\varepsilon \mho ̋ \chi \varepsilon \sigma \theta \varepsilon$ vं $\pi \dot{\varepsilon} \rho \dot{\eta} \mu \tilde{\omega} v$ [„imádkozzatok értünk”]), valamint a szokványos átokformulákról ismerhetők fel, amelyekből hiányoznak a pogány istenségekre tett utalások. A feliratok előkerülésük helye és gyártóműhelyeik szerint csoportokat alkotnak. Az egyik legkülönlegesebb a III-IV. században a Felső-Tembris-völgyben

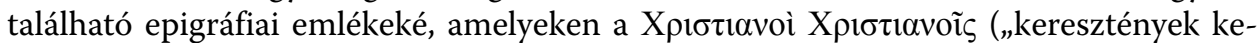
resztényeknek") felirat olvasható. ${ }^{58} \mathrm{Az}$ itt élő keresztények láthatóan nem ódzkodtak attól, hogy nyíltan megnevezzék vallási hovatartozásukat. A feliratok többsége azonban az ún. kriptokeresztény szövegekhez tartozik, amelynek legkorábbi és legismertebb darabja Hierapolis püspökének, Aberkiosnak (meghalt Kr. u. 167 körül) metrikus sírfelirata, amelynek bibliai utalásait az alábbiakban fogjuk elemezni. Ez a felirat annyira ismert volt, hogy szó szerint átvéve másolták is (például IGR IV 694, Karadirek, Kr. u. 216). Az Eutropius síroltárán (MAMA XI, 145, Kr. u. 200-250 körül) szereplő 22 soros hexameteres sírversben is egyaránt találunk klasszikus és bibliai reminiszcenciákat (lásd alább a 6.1.2. fejezetet).

\section{Oktatás, írásbeliség, műveltség}

A hellenisztikus korban visszafordíthatatlan nyelvi változás indult meg a Phrygiában: az írásbeliségben a paleo-phryget kiszorította a görög; Alexander Petrie szavaival élve „a görög kiirtotta Anatólia bennszülött nyelveit". ${ }^{59}$ A szóbeliségben a phryg nyelv továbbra is

${ }^{56}$ W. M. Calder: Early-Christian Epitaphs from Phrygia. AS 5 (1955) 25-38; É. Chiricat: The 'CryptoChristian' Inscriptions of Phrygia. In: Roman Phrygia. Culture and Society. Ed. P. Thonemann. Cambridge (2013) 198.

57 A két legkorábbi datált felirat Kadoiban került elő: Kr. u. 157/8-ból (SEG XLI, 1073) és 179/80-ből (SEG XV, 795), az itteni mủhelyben készült feliratokon egy körben vagy koszorúban elhelyezett tau-kereszt látható.

${ }^{58}$ Kiadásuk: Gibson: i. m. (34. j.). Értékelésükhöz lásd G. J. Johnson: A Christian Business and Christian Self-identity in Third/Fourth Century Phrygia. VChr 48 (1994) 341-366.

59 „Killed out the native languages of Anatolia” (A. Petrie: Epitaphs in Phrygian Greek. In: Studies in the History and Art of the Eastern Provinces of the Roman Empire. Ed. W. M. Ramsay. London (1906) 119-136, kül. 134); vö. C. Brixhe: La langue comme critère d'acculturation: l'exemple du grec d'un district phrygien. In: Acta Anatolica E. Laroche oblata (Hethitica 8). Ed. R. Lebrun. Louvain - Paris (1987) 45-80; Mitchell: $i$. $m$. (5. j.) 174 . 
őrizte elsőségét, de a felgyorsuló urbanizáció révén lassanként - legalábbis a városlakók között - az orális kommunikációban is átvette szerepét a koiné. A nyelvi és kulturális hellenizáció legfőbb eszköze természetesen Phrygiában is a paideia volt, amelynek átadásához oktatásra: vagyis tanítókra (paidagógosokra, grammatikusokra, rétorokra) és oktatási intézményekre volt szükség. ${ }^{60}$ Egyelőre viszonylag kevés adatunk van tanítókra

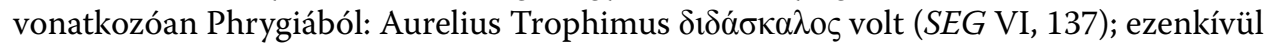

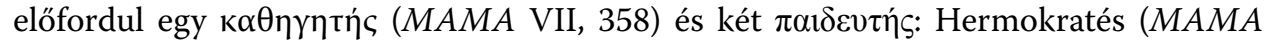
IX, 445; Aizanoi, Kr. u. 150-175) és Damoxenos (MAMA IX, 477; Aizanoi, Antoninus-kori). A Lydia északi részén (a mysiai határ közelében) fekvő Iulia Gordosban előkerült emlékművön a „Démos; gyermekek; ifjak; tanulók; ephébosok; a Theodoton alatt

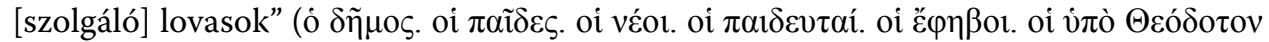
i $\pi \pi \varepsilon i \varsigma$, , TAM VI, 700) felirat szerepel. A város, amely a Flaviusok korában nyerte el a polis rangot, nem sokban különbözhetett a phrygiai kisvárosoktól. A felirat tanulsága, hogy még ezeken a kis településeken is nagy hangsúlyt helyeztek az ifjúság képzésére. Hierapolisban egy Héliodóros nevű tanárnak emeltek sírfeliratot tanártársai (SEG LIV, 1338);

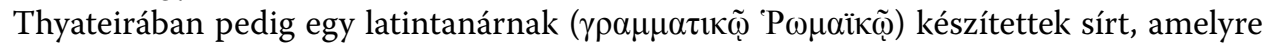
egy latin verset is véstek: „vota supervacua fletusque et numina divum / naturae leges fatorumque $\mathrm{ar}<\mathrm{g}>$ uit ordo. / sprevisti patrem matremque, miserrime nate, / Elysios campos habitans et prata veatum" (TAM V/2,1119). A tanár Pollianosnak Akmoneiában állítottak verses feliratot: „Pollianos, Pollianos fia, aki Phóteinos fia, ezt az írást az összes Múzsának készítettem, és ezt mondom az elhaladóknak: a Múzsák között éltem,

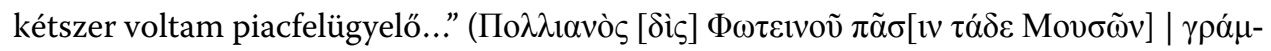

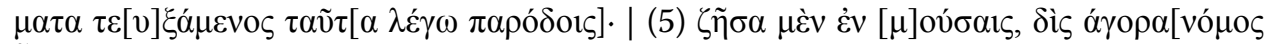
ฑิेv]..., Ramsay, CB II.1. p. 658, no. 611; SGO III 16/03/03).

A phrygiai írásbeliség viszonylag magas szintjére - és nem csupán a városi lakosság körében! - több olyan példát tudunk felhozni, amely csak itt fordul elő a Római Birodalomban. A sírdomborműveken ábrázolt írótáblák és papirusztekercsek mellett (lásd fentebb a 4.2. pontban) ilyennek tekinthetjük a 4.3.1. pontban már tárgyalt „engesztelö” vagy „bünvalló” feliratokat, amelyek jellemzően a II-III. században keletkeztek. Ezen a vidéken Nicole Belayche szerint a mezőgazdasági munkás nem egyenlő az írástudatlannal. ${ }^{61}$ A 150 darab „engesztelő” vagy „bűnvalló” felirat túlnyomó része ugyanazon a területen került elő, ahol ekkor már a kereszténység is jelentkezik a feliratokon. Eckhardt Schnabel véleménye az, hogy ez a jelenség valamifajta versengésre utal a pogány és keresztény lakosság között, mivel az engesztelő feliratok lényege, hogy a pogány istenség

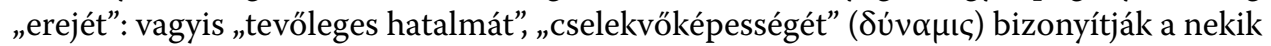

${ }^{60}$ O. P. Pelcer-Vujačić: Society in Lydia and Phrygia from the 1st to the 3rd Century AD. Ph.D. diss. University of Beograd (2015) 225-230.

${ }^{61}$ N. Belayche: Functions of Writing in the Religious Epigraphy of Roman Anatolia: From Monumentum to Efficacious Writing. RHR 230 (2013) 253-272. 
felállított sztéléken keresztül. ${ }^{62}$ Claude Brixhe amellett érvelt, hogy ezeket a sztéléket a szentélyek személyzete jegyezte le a hívők elbeszélése után; María Paz de Hoz szerint azonban maguk a hívők írták ezeket a szövegeket. ${ }^{63}$ Szerinte a „keresztények a keresztényeknek" formulát tartalmazó feliratok (lásd a 4.3.2. pontban) szintén az írásbeliség széles körü elterjedését mutatják. ${ }^{64}$

A sírfeliratok gyakran szólítják meg az arra járókat, hogy olvassák el azok szövegét. Az alábbi három példa mind Appiában (Pınarcık-Abya) előkerült sírfelirat. Heortasios epitáfiumának mindjárt az első sora egy felszólítás: „állj meg már, idegen, és olvasd

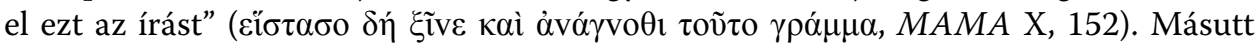

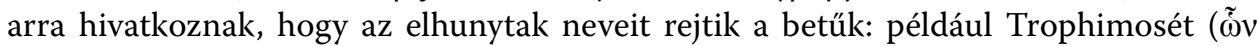

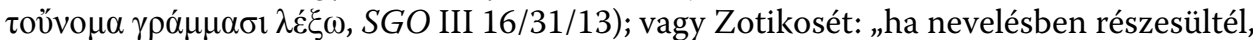
olvasd el ezt a sír[feliratot], akinek kedvéért ez az emlék betúkkel bevésetett" ( $\pi \alpha 1 \delta \varepsilon i ́ \alpha \varsigma$

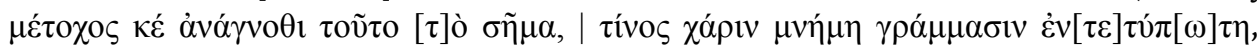
SGO III 16/31/17). Ez utóbbi különösen azért érdekes, mivel megtudjuk belőle, hogy a $\pi \alpha \iota \delta \varepsilon i ́ \alpha$ - a mai angol literacy kifejezéshez hasonlóan - alapvetően írni és olvasni tudást jelentett. ${ }^{65}$

Természetesen Phrygiában is jelen voltak a különféle „értelmiségi szakmák” képviselői, akiket rendszerint tudásukért és műveltségükért is dicsérnek az epitáfiumokban. Asklepiadés, aki orvos és költő volt egy személyben, „a Múzsák ékesszóló szolgájának,

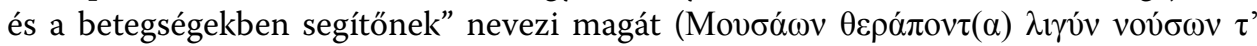
غ̇ं $\alpha \rho \omega \gamma o ́ v, ~ M A M A$ IX, p. 29. no. 74 = SGO III 16/03/08). Egy Gaios nevű keresztény

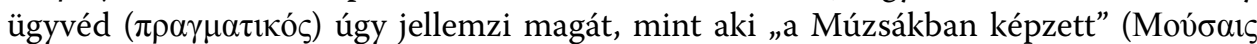

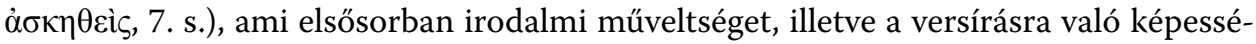
get jelentett, mint az az alábbi sorokból is kiderül: „fáradságos munkával szert tettem

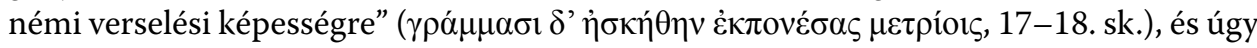
látszik, másoknak is írt verseket: „Ezekkel barátaim segítségére voltam, és amennyire

${ }^{62}$ Schnabel: $i$. m. (43. j.). A kereszténység szóhasználatában is Isten/Krisztus fontos tulajdonsága a

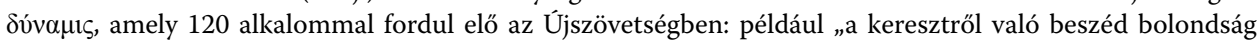
ugyan azoknak, akik elvesznek; de nekünk, kik megtartatunk, Istennek ereje” (1Kor 1,18); „mert nem beszédben áll az Istennek országa, hanem erőben” (1Kor 4,20); „a Krisztus ereje lakozzék én bennem” (2Kor 12,9); „noha megfeszíttetett erőtlenségből, mindazáltal él Istennek hatalmából” (2Kor 13,4); „a mi evangéliumunk ti nálatok nem áll csak szóban, hanem isteni erőkben is" (1Thesz 1,5) stb., lásd P. Gräbe: The Power of God in Paul's Letters (WUNT II. 123) Tübingen (2008).

${ }^{63}$ C. Brixhe: Individu, langue et communauté sociale: á propos des confessions paiennes du Moyen Hermos. In: Norma e variazione nel diasistema greco. Atti del Quarto Incontro Internazionale di Linguistica Greca. Eds. C. Consani - L. Mucciante. Chieti-Pescara (1999) 101-118; M. Paz de Hoz: Literacy in Rural Anatolia: The Testimony of the Confession Inscriptions. ZPE 155 (2006) 139-144.

${ }^{64}$ Egyébként ezeken is sok írótábla szerepel, lásd Gibson: $i$. m. (34. j.) nos. 3, 4, 5, 11, 12, 16, 30.

${ }^{65}$ További példa: „te pedig, ó vándor, ne fordíts hátat, hanem olvasd el ezt az írást, és emlékezz, ó ha-

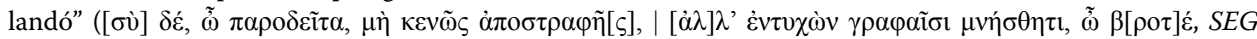
XXXV, 1391 = SGO III 16/32/02, ll. 6-7, Kotiaion, III. század). 
tőlem telt, buzgalmamat mindenki rendelkezésére bocsátottam" (19-21. sk.). ${ }^{66}$ A sír-

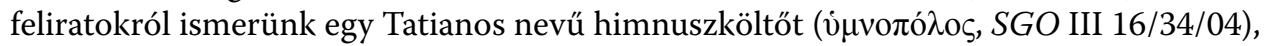

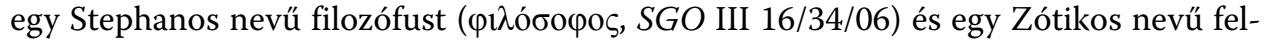

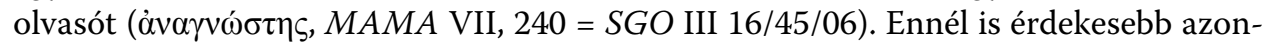
ban Zótikos síremléke a Phrygiai Felföldről (Yapıldağ), amelyben az elhunytat „föld-

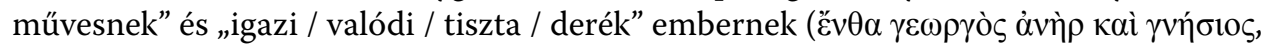
SGO III 16/41/10) írja le az epitáfium, amelyben egy klasszikus mitológiai allúziókat tartalmazó verses átokformulát is találunk: „Aki ezt a síremléket gyalázatos módon nem

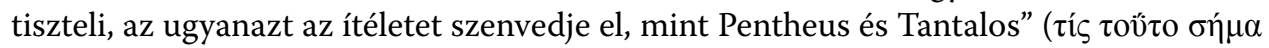

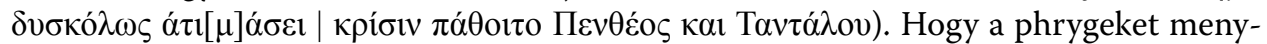
nyire jellemezte a bölcsesség szeretete, mi sem mutatja jobban, mint hogy valaki szülö-

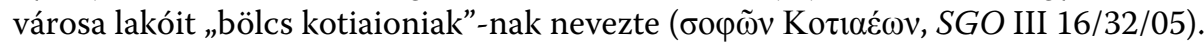

\section{Intertextualitás a sírfeliratokon}

Homéros jelentőségéről a kis-ázsiai sírköltészetben nemrégiben részletes monográfiát adott közre Gregor Staab. ${ }^{67}$ Ebben megállapította, hogy Homéros ismerete Anatólia legeldugottabb sarkában is jelen volt. Phrygiában a homérosi költészet olyan kulturális koinét jelentett, amelynek nyelvét pogányok, keresztények, sőt talán még a zsidók is egyformán beszélték. Az alábbiakban néhány jellemző példán keresztül - a teljesség igénye nélkül - fogom megmutatni az intertextualitás működését homérosi és bibliai reminiszcenciákkal teleszőtt phrygiai epitáfiumok szövegein keresztül.

\subsection{Görög-római irodalmi szövegek}

Phrygia - mint a bevezetőben láttuk - sok szállal kötődik a homérosi eposzokhoz. Az itteni városok és lakóik számára is fontos volt a „jó származás” ( ezért gyakran utalnak a hőstörténetekre (Otreus és Mygdón, Akamas és Askanios történetei: Hom. Il. II, 823, 862; III, 184-189; XII, 100; XIII, 790). ${ }^{68}$ A homéroszi eposzok

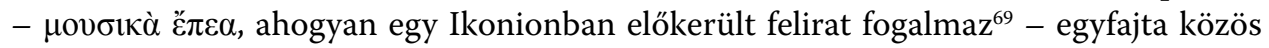

${ }^{66}$ IGR IV, 743 = SEG VI, 210 = SGO III 16/06/01, a Felső-Maiandros körzetében, Işıklı falu mellett (42 km-re Apameia Kibótostól északnyugatra) került elő. A sírkő felső részén törött, eredeti magassága $117 \mathrm{~cm}$, legnagyobb szélessége 40,5 cm, maximális vastagsága $50 \mathrm{~cm}$, a betűk magassága 1,8-2 cm között változik. A síremléket ( $\tau$ $\mu \beta 0 \varsigma$ ) egy házaspár: Gaios és felesége, Tatia készíttette magának és gyermekeiknek, akiket nem nevez meg a felirat.

${ }^{67}$ G. Staab: Gebrochener Glanz. Klassische Tradition und Alltagswelt im Spiegel neuer und alter Grabepigramme des griechischen Ostens (UALG 130). Berlin - Boston (2018) 39-48.

${ }^{68}$ Ezek a hérósok Stektorion, Akmoneia, Dorylaion és Synnada pénzein is megjelennek, lásd Kelp: $i . m$. (30. j.) 88. n. 37.

${ }^{69}$ H. S. Cronin: First Report of a Journey in Pisidia, Lycaonia, and Pamphylia II. JHS 22 (1902) 339-376,

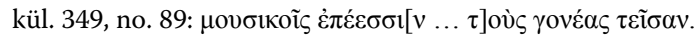


kulturális bázist képeztek Phrygia lakói számára, függetlenül attól, hogy városban vagy vidéken laktak-e; a görög-római isteneket tisztelték, vagy valamelyik keresztény felekezethez tartoztak. Thonemann szerint ez legalább annyira megdöbbentő, mintha a modern Tennessee marhapásztorai a Beowulfból vett idézetekből fogalmaznák meg saját sírfelirataikat. Valójában ennél többről van szó. A homérosi eposzok a phrygiai identitás alapját képezték - olyan alap volt ez, amely a legnagyobb megbecsülést élvezte az egész kulturált világban Indiától Britanniáig. A phrygiai emberek a homérosi világ közvetlen örököseinek érezték magukat, ami a legelőkelőbb származást jelentette az oikumenében. Talán szerencsésebb lett volna azt a modern példát mondani, hogy a római korban keletkezett phryg sírfeliratok homérosi versei olyanok, mintha ma egy bajor paraszt a Nibelung-énekből vett idézetekkel vagy egy norvég pásztor skáld-versekben írná meg sírfeliratát.

\subsubsection{Pogány feliratokon}

A kelet-phrygiai sztyeppén található Axylon alapvetően kisfalvas térség volt, amelyben a nagy kiterjedésű császári és magánbirtokok domináltak. Megdöbbentő, hogy erről az alapvetően rurális területről is több tucat metrikus sírfelirat került elő. Peter Thonemann azt írja: „Az észak-phrygiai Felső-Tembris-völgy kivételével nem ismerek a Római Birodalom keleti felében egyetlen olyan rurális területet sem, amely ehhez hasonló mennyiségű verses epitáfiumot produkált volna" ${ }^{70}$ Thonemann véleménye szerint a verseket falusi iskolamesterek írhatták. Legjellemzőbb tulajdonságuk, hogy mindegyik homérosi reminiszcenciákból építkezik: a verseknek gyakorlatilag minden sorában találunk olyan frazémákat, amelyek az Ilias és az Odysseia igen alapos ismeretéről tanúskodnak. (A kutatás ezeket nevezi „Homeric tag”-eknek.) Ráadásul ezek a sírfeliratok más görög költőket nem is idéznek. Míg a nagyobb városokban előfordulnak Hésiodostól, Kallimachostól vagy Menandrostól kölcsönzött idézetek is, Phrygia rurális területein mintha Homéroson kívül mást nem is ismertek volna. ${ }^{71}$ Ugyanakkor - mint ahogyan Thonemann meggyőzően kimutatta - ezek a falusi iskolamesterek igencsak hadilábon álltak a verseléssel. ${ }^{72}$ Ez vonatkozik arra a három költőre is, akiket Axylonban és annak környékén sikerült azonosítani. ${ }^{73}$

A bölcsességet és műveltséget mind a férfiakban, mind a nőkben dicsérik. Tati-

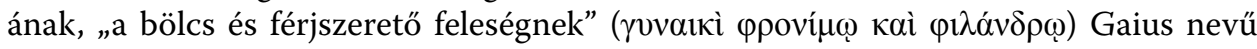

70 P. Thonemann: Poets of the Axylon. Chiron 44 (2014) 191-232, kül. 193.

${ }^{71}$ A bithyniai Nikomedeiában került elő egy felirat, amelyben egy bizonyos Kyrónt Hésiodos, Ar-

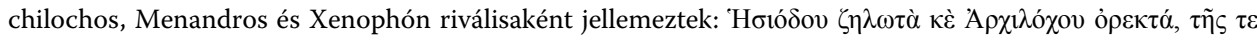

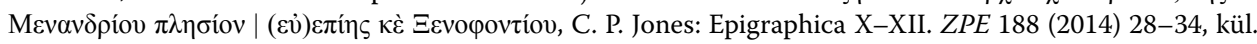
$31-33$.

${ }^{72}$ Thonemann példája egy kappadokiai epitáfium (SGO III 13/08/01), amelyben szinte minden kifejezés Homérostól lett kölcsönvéve, de a disztichon metrikailag csapnivaló.

73 „Zıvarık-költő” (II, Nos. 1-4), „Çeşmelisebil-költő” (III, Nos. 5-7) és „Koçaş-költő” (IV, Nos. 10-11). 
házastársa állított síremléket (MAMA XI, 76; Kırka, Kr. u. 175-250). Balbilla ismeretlen

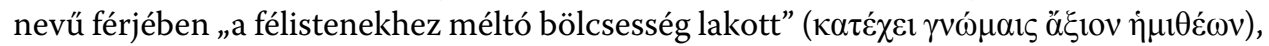
feleségében pedig olyan intelligencia és férjszeretet, amely Pénelopéval tette őt egyen-

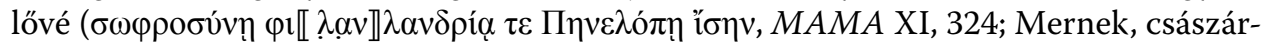
kor). Egy Alexandros nevű orvos feleségét, Secundát úgy jellemezték sírfeliratában, hogy „kitűnt bölcsességével és kiválóságával beszédben és minden női munkában” ( $\dot{\eta} \delta$ '

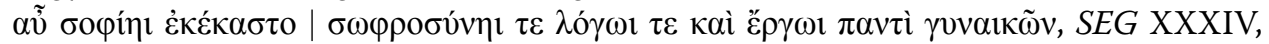
1290 = SGO III 16/53/03, Dokimeion, III. század). A hosszú nevű Gaius Claudius Egnatius Vigellius Valerius Ulpius Antonius Pollio Terentullianus - akinek ősei Asia tartományi főpapjai voltak - Asklépios papjaként működött, és ebbéli minőségében dicsérik

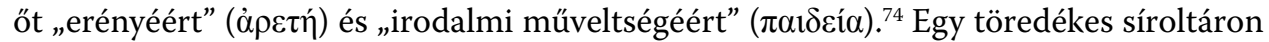
Bocchos állíttatott magának és szeretett feleségének - a császárkultusz kétszeres pap-

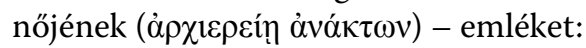

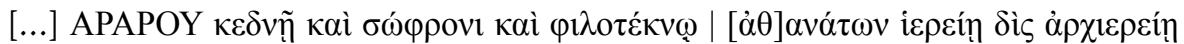

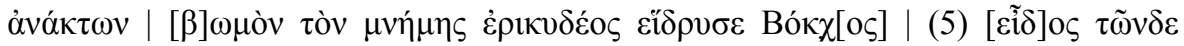

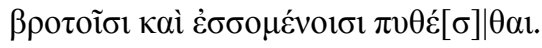

[A (férjnek) és (feleségnek)... ], aki szorgalmas, józan, gyermekeit szerető, a halhatatlanok papnője, az Urak [ti. a császárok] kétszeres főpapnője, Bocchos állította ezt a síroltárt az ő dicső emlékére, hogy azok a halandók is megismerhessék ennek a két (embernek) képmását, akik még ezután jönnek.

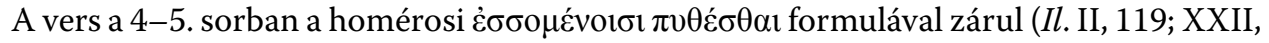
305; Od. XI, 76; XXI, 255; XXIV, 433), amit az eposz többek között Elpénór sírhalmának

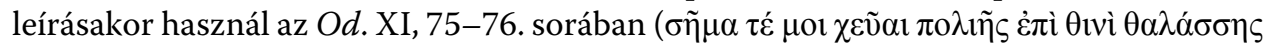

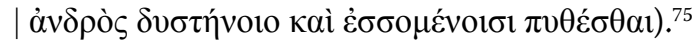

A homérosi reminiszcenciák sorát szinte vég nélkül gyarapíthatnánk. Onésimos,

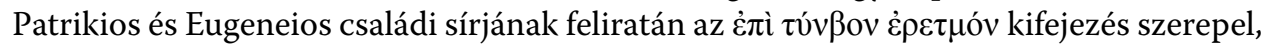

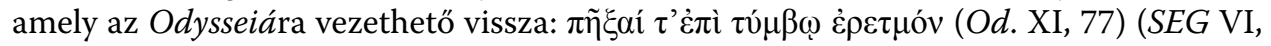
144 = SGO III 16/31/94, Dorylaion). Alexandra sírversének 3. verssorában olvassuk: „az

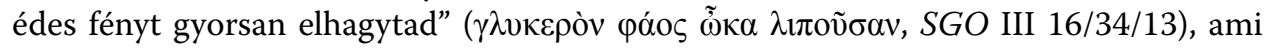

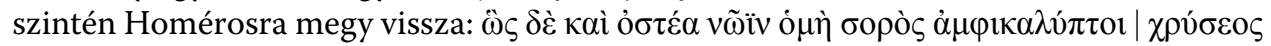

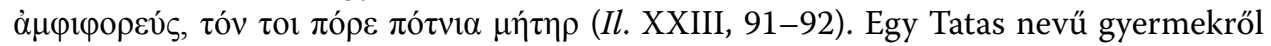

74 A paideiáról lásd még L. Robert: Études anatoliennes. Recherches sur les inscriptions grecques de

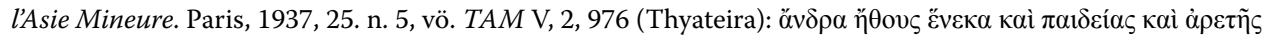

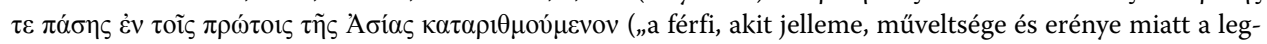
elsők között tartottak számon Asiában").

75 A kifejezés egyébként elég gyakori a közép-anatóliai sírversekben: I.Klaudiu Polis 78; I.Beroia 400; J. G. C. Anderson: Explorations in Galatia cis Halym. JHS 19 (1899) 34-134, 280-318, kül. 287, no. 185 (Kuyulusebil); G. Laminger-Pascher: Die kaiserzeitlichen Inschriften Lykaoniens. Faszikel I: Der Süden. Wien (1992) 190-191, no. 306, l. 18 (Dineksaray). 
az olvasható, hogy a halál azelőtt ragadta el, hogy „elérte az ifjúság mértékét”, vagyis if-

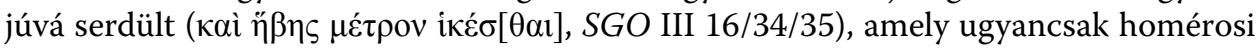
kifejezés (például Od. IV, 668; XI, 317; XVIII, 217 stb.). Diogenés töredékes sírfeliratán

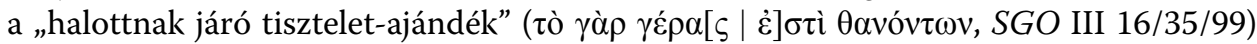
kifejezést találjuk, amiről a Sarpédón haláláról szóló részben olvashatunk: „mert ez a

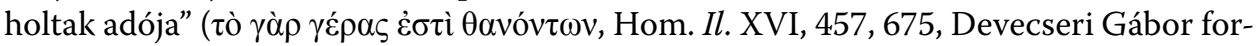
dítása); de a kifejezés más feliratokon is előfordul (SGO III 16/36/02, Midaion; 13/07/02, Tyana). A pisidiai Antiochiában élő Pomponia azt írja férjéről, aki orvos volt, hogy „őt

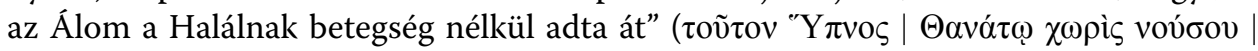
$\pi \alpha \rho \varepsilon ́ \delta \omega \kappa \varepsilon v, S G O$ III 16/61/11), ami ugyancsak a Sarpédónról szóló részekben szerepel,

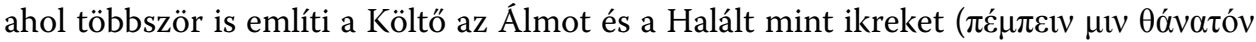

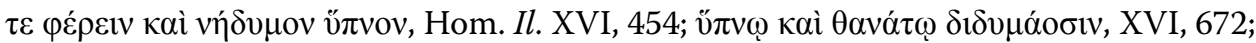

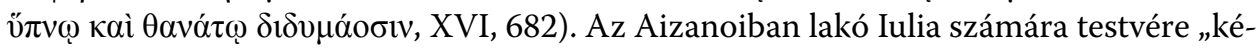

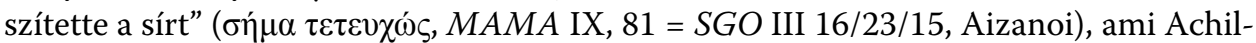
leus szavait idézi ( $\sigma \eta ́ \mu \alpha \tau \varepsilon \tau \varepsilon v ́ \xi \varepsilon \tau \alpha$, Hom. Il. XXI, 322).

\subsubsection{Keresztény feliratokon}

A phrygiai keresztények semmivel sem voltak kevésbé „lokálpatrióták” és semmivel sem kevésbé büszkék klasszikus műveltségükre, mint a körülöttük élő pogányok. A Kyria, Basilissa és Palladios síremlékén szereplő felirat így szól: ${ }^{76}$

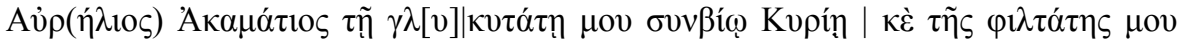

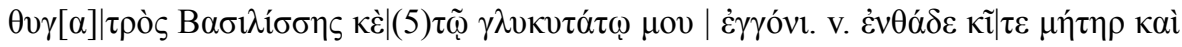

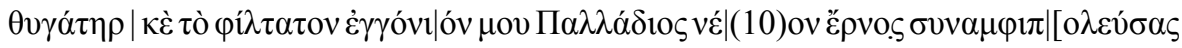
[?] -.... - ]

Aur(elios) Akama(n)tios, legdrágább feleségemnek, Kyriának, és legkedvesebb lányomnak, Basilissának, és legdrágább unokámnak. Itt nyugszik anya és lánya, és legkedvesebb unokám, Palladios, az „új hajtás”, aki felügyelőként [?] szolgált...

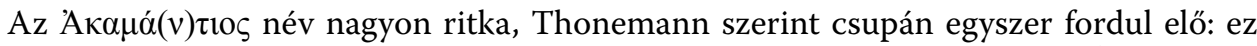
volt a mellékneve (adnomen) Q. Voconius Aelius Stratonikosnak, akit az „Új Akamas” névvel tiszteltek meg, mint Dorylaion új alapítóját, ${ }^{77}$ amit a hagyomány szerint Akamas, Théseus fia alapított. ${ }^{78}$ A 9-10. sorban előforduló véov ěpvoৎ valószínűleg homérosi re-

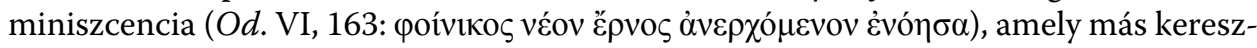

${ }^{76}$ MAMA XI, 312, no. 361, Kana (Beşağll), III-IV. század, a bómos akrotérionjában középen egy körben elhelyezett chi-rhó monogram, jobbról-balról pedig egy-egy galamb látható, http://mama.csad.ox.ac.uk/ monuments/MAMA-XI-361.html.

77 SGO III 16/34/06, 07, 09; Robert, OMS VI, 450-452.

78 Robert, OMS IV, 90-91; VI, 451-452. 


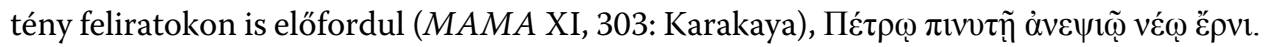
Az ع̌pvoৎ költői kifejezés elég gyakori a lykaóniai és Axylon környéki keresztény feliratokon. ${ }^{79}$ Az alábbi szövegekben arra látunk példákat, hogy a klasszikus allúziók hogyan keverednek bibliai kifejezésekkel a keresztény feliratokon.

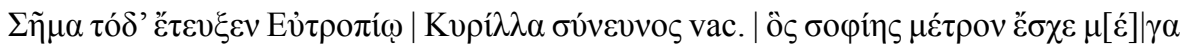

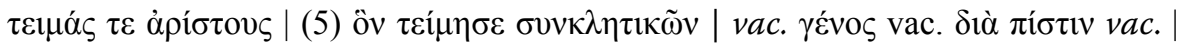

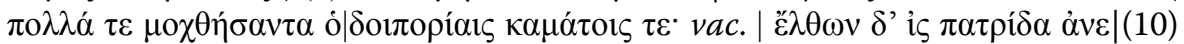

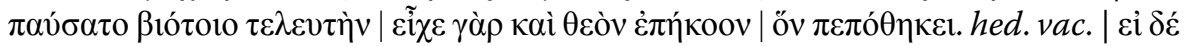

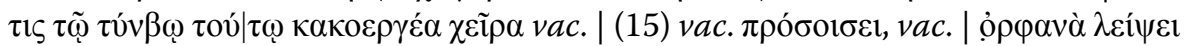

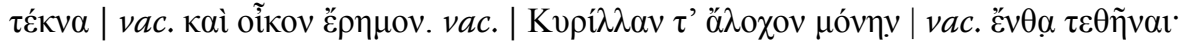

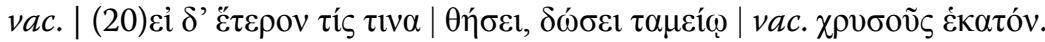

Ezt a síremléket felesége, Kyrilla készítette Eutropiosnak, akinek bölcsessége nagy volt, $\mathrm{s}$ akit senatorok nemzetsége tisztelt meg a legnagyobb megtiszteltetéssel hüségéért, miután életében sokat fáradt a kimerítő utazásoktól. Miután visszatért szülőföldjére, élete alkonyán nyugalmat talált, mivel egy (ima)meghallgató Istene volt, akire vágyott. Ha bárki ártó kezet vet erre a sírra, annak gyermekei árván maradnak, és háza elhagyatik. Csak feleségét, Kyrillát lehet ide temetni, és ha valaki mást ide temet, az fizessen a kincstárnak száz aranyat.

A $118 \mathrm{~cm}$ magas márvány síremlék $(\sigma \tilde{\eta} \mu \alpha)$ teteje fenyőtoboz alakban végződik, és Roberts szerint akmoneiai műhelyben készült. ${ }^{80}$ A síremlék (3. ábra) bal és jobb oldalán íróeszközök láthatók: egy papirusztekercs és egy tolltartó, amivel - Peter Thonemann értelmezése szerint - „a klasszikus kultúra ismeretét akarta jelezni”.

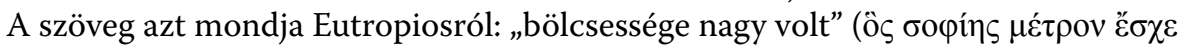
$\mu \varepsilon ́ \gamma \alpha$ ), ami nem csupán elméleti tudásra, hanem gyakorlati bölcsességre is utalhat. Eut-

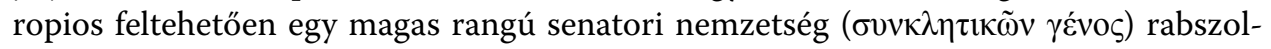
gája lehetett, aki élete során sokat fáradt kimerítő utazásoktól ( $\pi 0 \lambda \lambda \alpha$ $\tau \varepsilon \mu \mathrm{o} \chi \theta \eta \dot{\sigma} \sigma \nu \tau \tau \alpha$

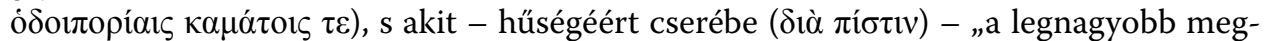

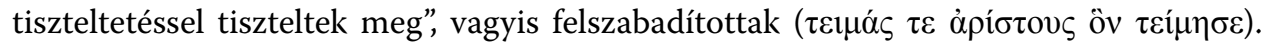
Thonemann szerint valamiféle intéző lehetett egy senatori birtokon, majd felszabadí-

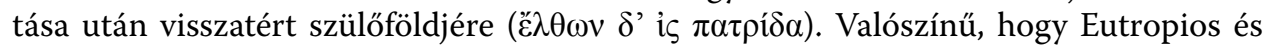

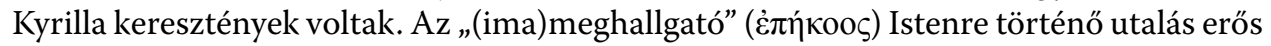

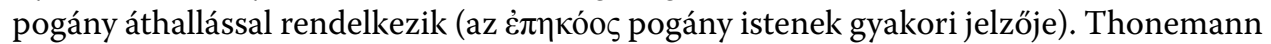
úgy tudja, hogy keresztény feliratokon nincs párhuzama, pedig elég erős bibliai konno-

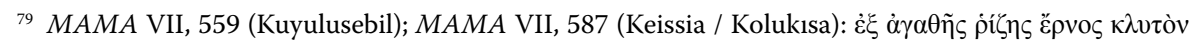

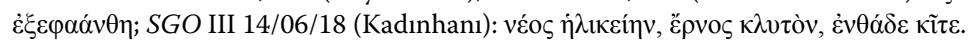

${ }^{80}$ MAMA XI, 145; Karasandıklı, Kr. u. 200-250. http://mama.csad.ox.ac.uk/monuments/MAMA-XI-145.html. 


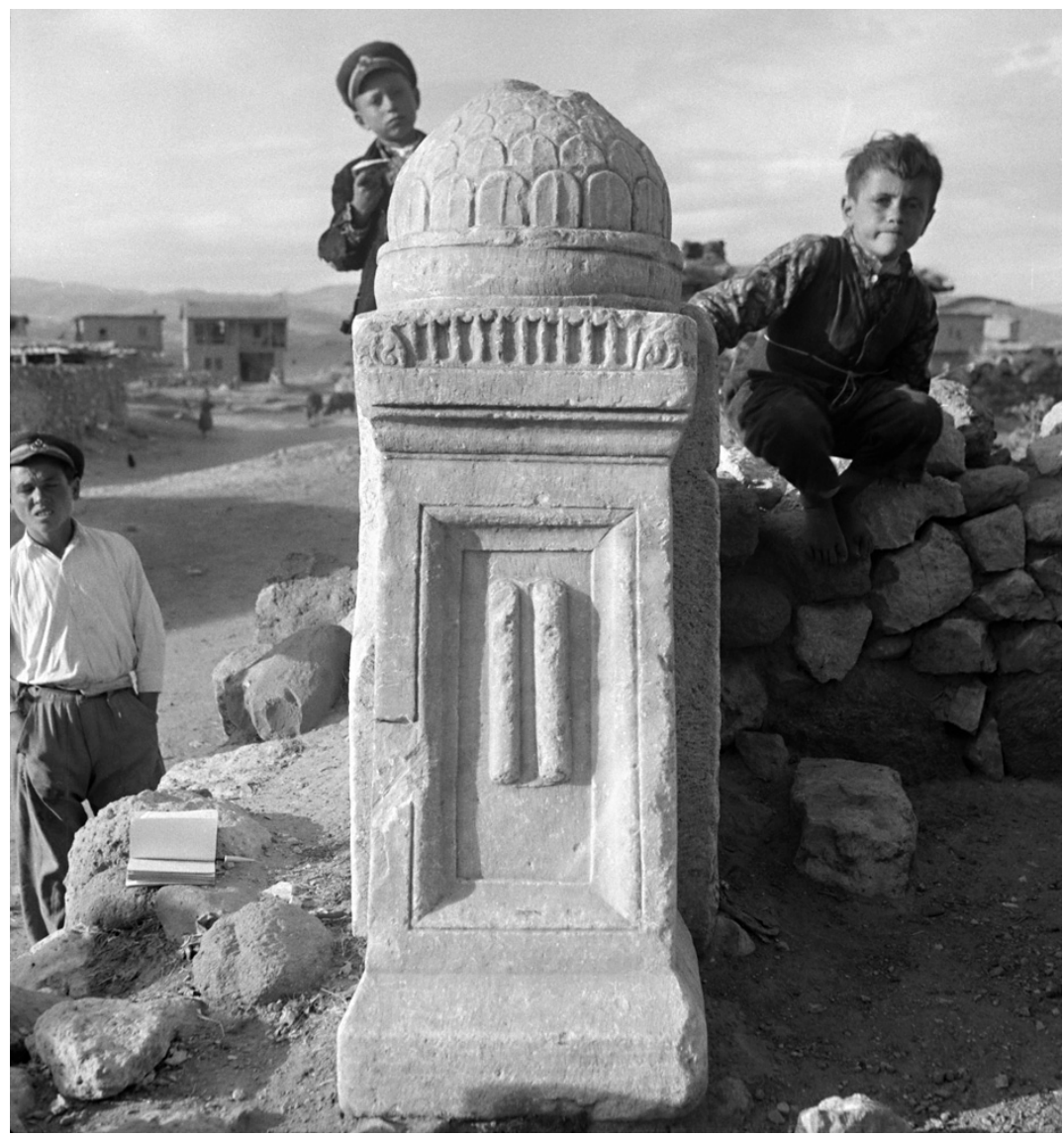

3. ábra. Papirusztekercs Eutropios síroltárán, Karasandıklı (Pentapolis), Kr. u. 200-250 között (MAMA XI, 145), 1955-ben készült felvétel. Forrás: http://mama.csad.ox.ac.uk/monuments/ images/ill/1955-39-3.jpg.

tációval rendelkezik (például 2Krón 6,40; Zsolt 40,1; 42,1; 119,20¹), az „akire vágyott” (őv $\pi \varepsilon \pi o ́ \theta \eta \kappa \varepsilon \imath)$ viszont tipikusan a zsidó-keresztények szóhasználatára jellemző. ${ }^{82} \mathrm{Az}$

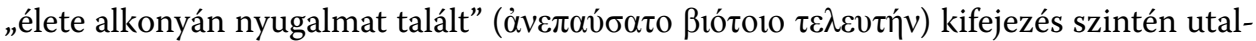

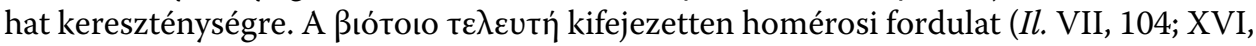
787), ami az $\alpha v \alpha \pi \alpha v ́ \varepsilon \sigma \theta \alpha$ kifejezéshez kapcsolódik, ez utóbbi keresztény kontextusban

${ }^{81}$ H. S. Versnel: Religious Mentality in Ancient Prayer. In: Faith, Hope and Worship. Aspects of Religious Mentality in the Ancient World (SGRR 2). Leiden (1981) 1-61, kül. 26-37.

${ }_{82}$ W. H. Buckler - W. M. Calder - C. W. M. Cox: Asia Minor V.: Monuments from the Upper Tembris

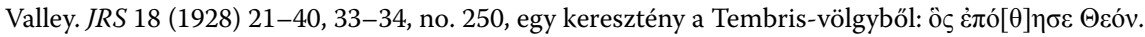


is gyakori (például TAM V 2,1159, Thyateira). Az átokformula egyaránt előfordul pogány és keresztény környezetben.$^{83}$ A bómos oldalán ábrázolt nyitott könyvtekercsről nehéz eldönteni, hogy Eutropios (és felesége, Kyrilla) klasszikus vagy bibliai műveltségére utal inkább.

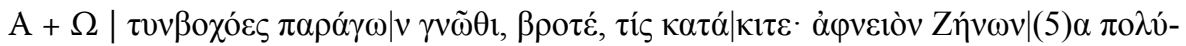

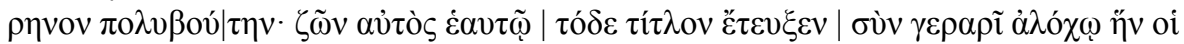

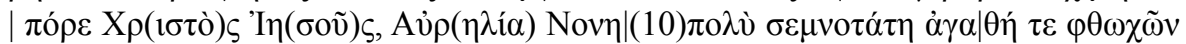
$\theta \rho \varepsilon \dot{\varphi} \varphi \eta\langle\rho\rangle^{\prime} \dot{\alpha} \mid \mu \omega ́ \mu \eta \tau \varepsilon \sigma o \varphi \eta ́ . ~ v a c$.

$\mathrm{A}+\Omega$ Ahogy elhaladsz e sírdomb mellett, ismerd meg, halandó, kik vannak itt eltemetve: Zénón, aki gazdag volt bárányokban és ökrökben. Még életében vésette magának ezt a feliratot ( $\tau i$ i $\lambda$ ov $\varepsilon$ $\tau \varepsilon v \xi \varepsilon v)$, együtt tisztelt feleségével, Aurélia Nónéval, akit Jézus Krisztus adott neki: ő egy igen tiszteletre méltó szent hölgy volt, a szegények gyámola, feddhetetlen és bölcs.

Bár ezen a nyilvánvalóan a konstantini fordulat után készült keresztény feliraton - Zénón és Aurélia Nóné szarkofágjának töredékén ${ }^{84}$ - nem szerepelnek írószerek, a kép és a szöveg együttese mintha azt az előfeltevést igazolná, hogy a phrygiai sírokon gyakran előforduló lábasjószágok az elhunyt férfi gazdagságát fejezik ki, az írótáblák

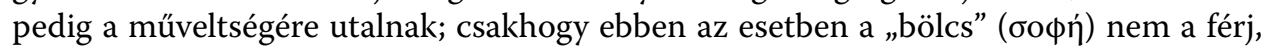
hanem a feleség. A 2. sorban előforduló tuvßoxócc egy hapax legomenon, amely az

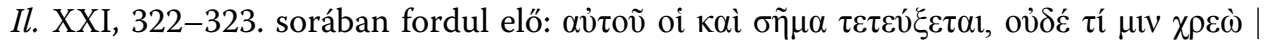

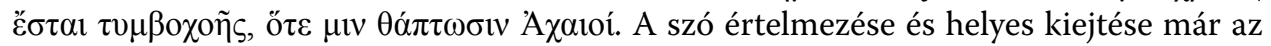
ókorban is vitatott volt, ${ }^{85}$ minden jel szerint a sírfelirat költője melléknévként értelmezte

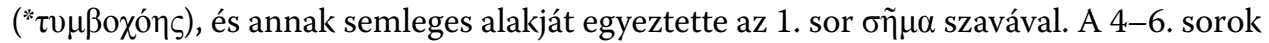

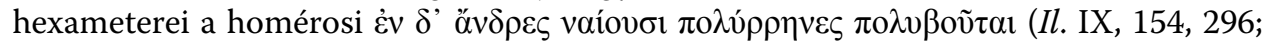
vö. Hés. frg. 240,3 ed. Merkelbach-West) sorra vezethetők vissza; és az 5. sor elején ol-

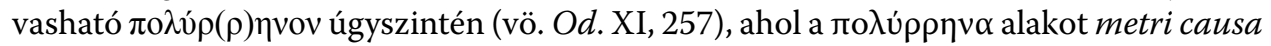

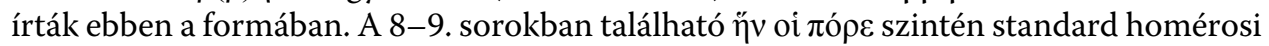

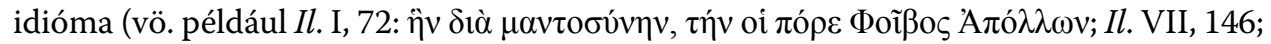
IX, 66; XI, 353; XVI, 441; XXIII, 92; Od. V, 321; V, 372; VI, 228).

Különösen a keresztény családokban figyelhető meg, hogy a feleséget nemcsak szépségéért, tisztaságáért, feddhetetlenségéért, hanem bölcsességéért is dicsérik a feliratok. ${ }^{86}$ Démétrianét, aki kiemelkedő volt „bölcsességben” (MAMA XI, 207; Çeşmeli-

${ }^{83}$ Ramsay, $C B$ II. p. 730, no. 658; J. Strubbe: Curses against Violation of the Grave in Jewish Epitaphs of Asia Minor. In: Studies in Early Jewish Epigraphy (AGAJU 21). Eds. P. W. van der Horst - J. W. van Henten. Leiden (1994) 70-128, 289-292.

${ }^{84}$ MAMA XI, 206; Çeşmelisebil, Kr. u. IV-V. század. http://mama.csad.ox.ac.uk/monuments/MAMA-XI-206.html.

${ }^{85}$ M. L. West: Some Homeric Words. Glotta 77 (2001) 118-135, kül. 135.

${ }^{86}$ MAMA V, 81 (Dorylaion); SEG XXXVII, 1099 bis (vö. SEG XL, 1197; Amorion). 


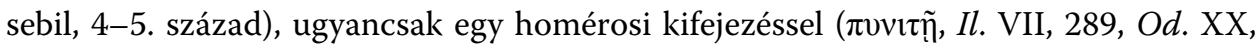
71) illette fia és annak felesége, „akit Jézus Krisztustól kapott”. Ez szerepel Glykeré di-

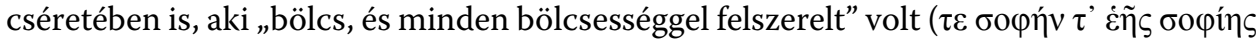

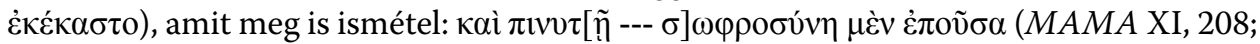
Çeşmelisebil, IV-V. század). A sírversben ugyan nincs közvetlen keresztény utalás, de szellemisége alapján talán annak tarthatjuk. A mindössze 15 évesen elhunyt lány, Den-

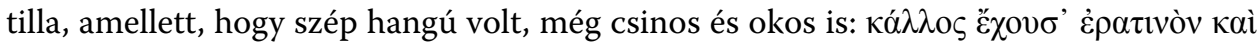

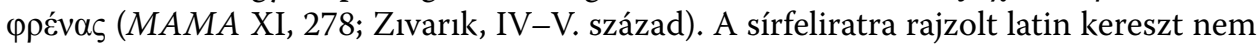
hagy kétséget afelől, hogy ő is keresztény volt.

Az eumeneiai Gelliát is szépségéért és bölcsességéért dicsérik verses sírfeliratában, amit férje, Flavius Pollio állított neki (SEG XXVIII, 1126 = SGO III 16/06/02):

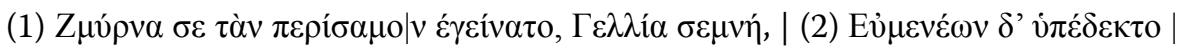

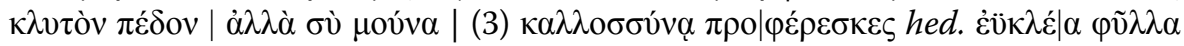

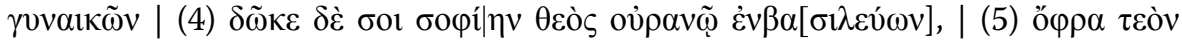

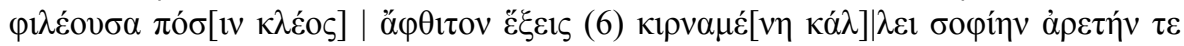
$\tau[\varepsilon \lambda \varepsilon i ́ \alpha v ?]$

Zmyrna szült téged, a nagyhírüt, tiszteletre méltó Gellia, | de Eumeneia híres síksága fogadott be, egyedül te | múltad felül szépségeddel az asszonyok dicső nemzetségét, | az égben uralkodó isten bölcsességet adott neked, | (5) hogy a te férjedet szeretve romolhatatlan hírnévre tegyél szert | a szépséggel a bölcsességet és a tökéletes erényt vegyítve.

Jogosan merül fel a kérdés, hogy mitől keresztény ez a felirat, hiszen az „égben ural-

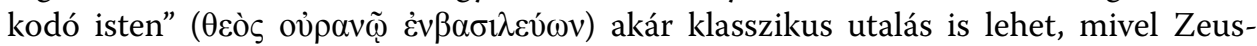
ról írja Hésiodos: „míg atyjukhoz mennek, Zeuszhoz, az égi királyhoz” (ô $\delta$ ' oủ $\rho \alpha v \tilde{a}$ $\dot{\varepsilon} \mu \beta \alpha \sigma \imath \lambda \varepsilon v ́ \varepsilon$, Theog. 71). Gregory Horsley hívta fel a figyelmet arra, hogy bár az „égben uralkodó isten" kifejezés ugyan szó szerint nem fordul elő az Újszövetségben, de Jézussal kapcsolatban többször is elhangzik, hogy uralkodik a Mennyben (Lk 1,33; 1 Kor 15,25; Jel 11,15.17; 19,6 stb.). Ugyancsak Horsley írja, hogy a bölcsesség mint Zeus ajándéka nem elterjedt motívum a pogány sírköltészetben, ${ }^{87}$ ezzel szemben az „Istentől kapott bölcsesség” igen gyakran előfordul az Újszövetségben (Ef 1,17; 1Kor 1,30; 12,8; 2Pét 3,15). Ráadásul Gellia isteni eredetű bölcsessége a férje iránti szeretetben nyilvánult meg, ami szintén keresztényi gondolat. ${ }^{88} \mathrm{~A}$ klasszikus utalások innen sem hiányoznak: a

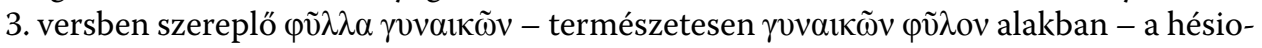

${ }^{87}$ „Wisdom as a gift of Zeus is not a common motif”, G. H. R. Horsley: New Documents Illustrating Early Christianity. A Review of the Greek Inscriptions and Papyri published in 1978. North Ryde (1983) 47-48, no. 14 .

${ }^{88}$ J. Pircher: Das Lob der Frau im vorchristlichen Grabepigramm der Griechen (Philologie und Epigraphik 4). Innsbruck (1979) 54. 
dosi Nők katalógusa első sorában szerepel (frg. 1,1 Merkelbach-West, vö. Theog. 1021);

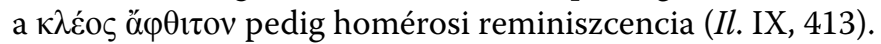

Természetesen nem csupán a nőkben, hanem a férfiakban is lakozhatott bölcses-

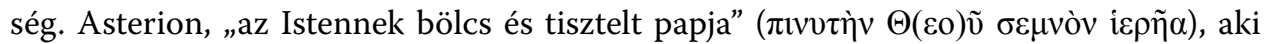

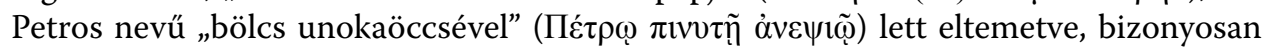
keresztény volt (MAMA XI, 303; Karakaya, IV-V. század). ${ }^{89}$ Ugyanez vonatkozik Trophimosra, Anteros fiára (SGO III 16/31/14, Appia, post Kr. u. 250):

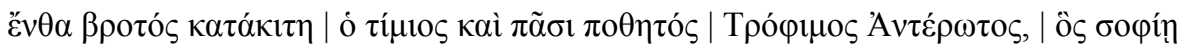

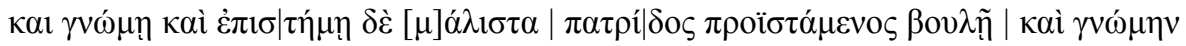

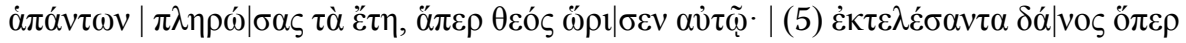

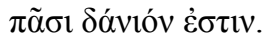

Itt nyugszik egy halandó, a tisztelt és mindenkitől vágyott Trophimos, Anteros fia, aki bölcsességben és értelemben, valamint tudományban, de leginkább a tanácsban - és minden dologban megmutatkozó ítélőképességben - élen állt szülővárosában; betöltötte az éveket, amelyeket az Isten kijelölt számára, és visszafizette az adósságot, amivel mindenki adós.

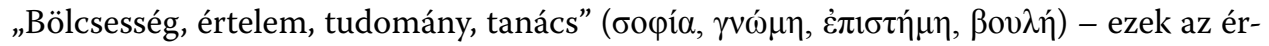
tékek és személyes tulajdonságok egyformán fontosak voltak a pogányoknak és keresztényeknek Phrygiában. Ahogy láttuk: a klasszikus művek - főként az archaikus eposzok - ismerete és némi verselési képesség is beletartozott ezek fogalmi körébe. De mit jelent a fenti szövegben a „visszafizette az adósságot, amivel mindenki adós” utalás? ${ }^{90} \mathrm{Ez}$ a kérdés átvezet minket a következő témához.

\subsection{Bibliai utalások}

Phrygia története még a trójai háborúnál is sokkal régebbre nyúlik vissza - egészen a vízözönig. A phrygiai vízözöntörténetet Ovidius Metamorphoseséből ismerhetjük meg (Met. VIII, 618-724), de a késő ókori Nonnos Dionysiakájában is szerepel, amelyben a két főhős nem egy házaspár (Dekalión és Pyrrha), hanem Priasos és apja, Brontios, akik jellegzetes phryg nevet viselnek (Non. Dion. XIII, 518-545). Apameia Kibótosban a phrygiai-görög vízözöntörténet a bibliai elbeszéléssel kontaminálódott; Ikonionban a város görög nevét (દíผ́v = „képmás”) arra vezették vissza, hogy a deukalióni vízözön után Prométheus itt formálta meg az ember prototípusát agyagból; és ugyancsak Ikon-

89 Papokra másutt is használják: I. Konya 206 (Yağlıbayat, Savatra).

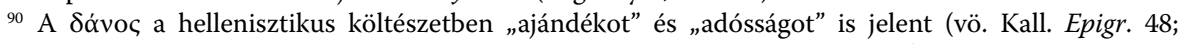
P. Masp. 126,11), fent az utóbbi értelemben áll. Bár ez a kifejezés nem szerepel az Újszövetségben, maga a

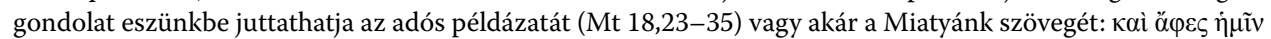

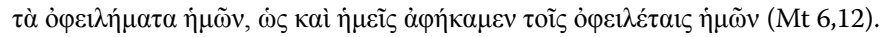


ion volt a hazája a legendás vízözön előtti királynak, Nannakosnak, aki sírásával előre jelezte a bekövetkező katasztrófát (Hdt. III, 10; Steph. Byz. s.v. 'Iкóviov). A vízözön történetén keresztül a zsidóság és kereszténység is valamennyire beilleszkedhetett az őshonos phrygiai kultúrába, hiszen a Biblia - ha nem is erre a területre vonatkozóan - szintén tartalmazta ezt a történetet. Talán ez is egyik oka lehet annak, hogy az itteni zsidók és keresztények sokkal nyíltabban tettek utalást a Szent Könyvekre, mint a Birodalom más területein. Antonio Enrico Felle Biblia Epigraphica katalógusa ugyan csak 14 közvetlen és közvetett idézetet sorol fel Phrygiából, ${ }^{91}$ de a valóságban ennél sokkal többel kell számolnunk. Ezen a területen számos keresztény felekezet működött, amelyek olykor meg is nevezik magukat: például a novatianusok és a montanisták ${ }^{92}-$ nem is szólva a számos gnósztikus szektáról. Ezek természetesen különböző módokon viszonyultak a Szent Iratokhoz. De érdekes, hogy Maximion püspököt sírfelirata mindjárt az

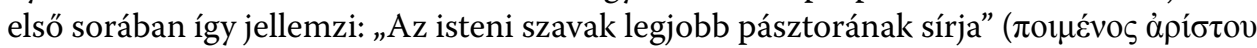

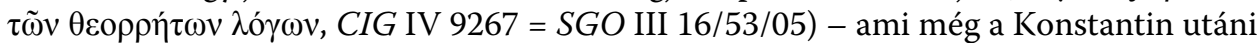
időszakban is ritkaság.

Valószínűleg a legkorábbi kriptokeresztény epigráfiai emlék a híres Aberkios-felirat, amely Hierapolis püspökének állít emléket (meghalt Kr. u. 167 körül). ${ }^{93}$ Aberkios életrajzát egy irodalmi forrás is megörökítette, amely a püspök sírfeliratának szövegét is közölte. ${ }^{94}$ Ennek nyomán Sir William Ramsay 1883-ban valóban meg is találta a felirat töredékeit egy fürdő romjai között Synnadában (Phrygia Salutaris). A vitában közölt és addig irodalmi fikciónak tartott - sírfelirat szövege segítségével tudták a megtalált töredéket rekonstruálni. A feliratot ma a Vatikáni Múzeum őrzi (Museo Pio Cristiano). A szöveget az alapján sikerült datálni, hogy Aberkios egyik földijének: egy hierapolisi polgárnak annyira megtetszettek a püspök szavai, hogy saját sírfeliratán szó szerint

91 A. E. Felle: Biblia Epigraphica. La Sacra Scrittura nella documentazione epigrafica dell'Orbis Christianus Antiquus (III-VIII secolo). Bari (2006) 227-233, nos. 489-502.

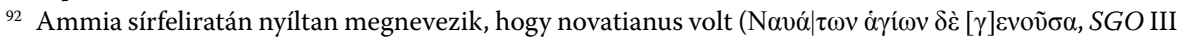

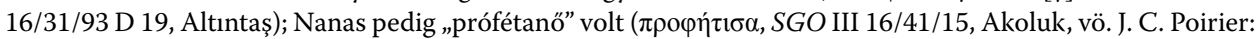
The Montanist Nature of the Nanas Inscription. Steinepigramme 16/41/15. EA 37 [2004] 151-159), minden bizonnyal a montanista egyházhoz tartozott. A montanista feliratokat összegyüjtötte: W. Tabbernee: Montanist Inscriptions and Testimonia: Epigraphic Sources Illustrating the History of Montanism. Macon (1997).

${ }_{93}$ IGR IV, 696 = IGUR II/1 15 = SEG XXX, 1479 = SGO III 16/07/01. Az Aberkios-felirat hatalmas mennyiségű szakirodalmat szült az elmúlt több mint egy évszázadban, itt csak néhány fontosabbat emelek ki időrendben: A. Abel: Étude sur l'inscription d'Abercius. Byzantion 3 (1926) 321-411; H. Grégoire: Encore l'inscription d'Abercius. Byzantion 8 (1933) 89-91; M. Guarducci: L'inscrizione di Abercio e Roma. AnSoc 2 (1971) 174-203; W. Wischmeyer: Die Aberkiosinschrift als Grabepigramm. JAC 23 (1980) 22-47; M. M. Mitchell: Looking for Abercius: Reimagining Contexts of Interpretation of the 'Earliest Christian Inscription'. In: Commemorating the Dead: Texts and Artefacts in Context: Studies of Roman, Jewish, and Christian Burials. Eds. L. Brink - D. Green. Berlin (2008) 303-336; M.-F. Baslez: L'épitaphe de l'éveque Aberkios: les Écritures de foi dissimulées sous l'écriture civique. JES 3 (2020) 149-166. (Lásd még az alábbi jegyzetekben.)

${ }_{94}$ Aberkios a Menologium Constantinopolitanum október 22-i szentje, életrajzát lásd Vita Abercii, PG CXV, 1212-1248, ed. Th. Nissen: Der Text der Aberkios-Vita. Leipzig (1912); vö. P. Thonemann: Abercius of Hierapolis. In: Historical and Religious Memory in the Ancient World. Eds. B. Dignas - R. R. R. Smith. Oxford (2012) 257-282. 
idézte annak első és utolsó sorát. ${ }^{95} \mathrm{Ez}$ utóbbi feliratot a helyi időszámítás (a Sulla-éra) 300. évére keltezték. Mivel tudjuk, hogy ennek kezdőéve Kr. e. 84, könnyen kiszámítható, hogy Kr. u. 216-ban írták a másik feliratot, amely tehát Aberkios epitáfiumának terminus ante quemje.

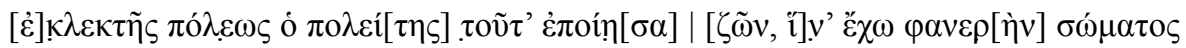

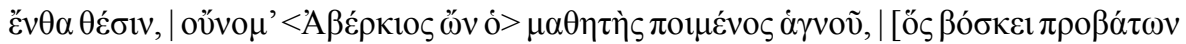

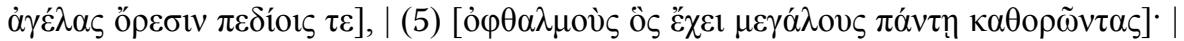

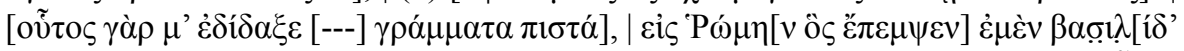

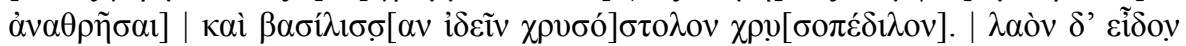

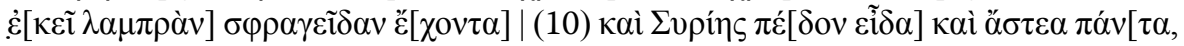

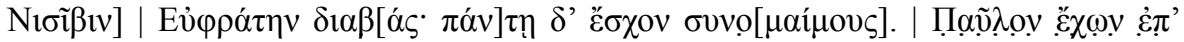

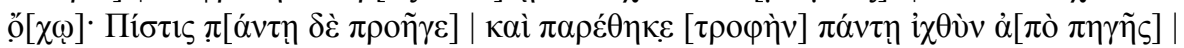

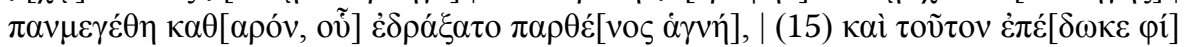

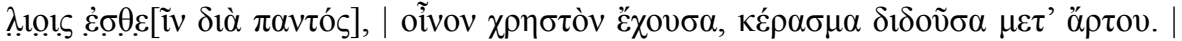

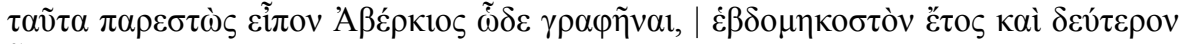

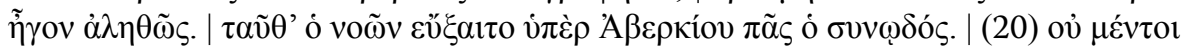

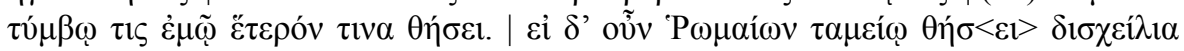

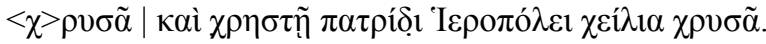

A választott város polgáraként készítettem ezt [a feliratot], | életemben, hogy legyen látható helye testemnek itt, | nevem Aberkios, a szent pásztor tanítványa, | aki legelteti juhnyáját a hegyeken és síkokon, | (5) akinek hatalmas szemei vannak, mindent áttekintők, | mert Ö tanított engem az élet igaz betűire. | Ô küldött engem Rómába, hogy lássam a birodalmat, | és lássam az aranyköpenyes, aranyszandálos királynőt. | Láttam ott a népet, fényes pecséttel megjelöltet, | (10) és láttam Syria síkját, és az összes várost, a Nisibis | [menti] Euphratésen átkelve, mindenütt voltak útitársaim: | Pál volt nálam; a hit vezérelt mindenütt, | és mindenütt ételt tettek elém: halat a forrásból, | hatalmasat, tisztát, amit kifogott a szent szűz, | (15) és ezt adta a testvéreknek enni örökre, | s mivel volt jó bora, kevert [bort] adott kenyérrel. | Ezeket én, Aberkios, személyesen mondtam, hogy írják le, | valóban hetvenkét évet éltem meg, | aki felfogta ezeket és aki egyetért, imádkozzék Aberkiosért, | (20) de senki ne tegyen valamely más testet az én síromba, | s ha megteszi, fizessen a római pénztárnak kétezer aranyat, | és az én kedves szülővárosomnak, Hierapolisnak ezer aranyat.

A 22 sornyi hexameterből álló, szándékosan enigmatikusan fogalmazó sírfelirat az egyik legkorábbi keresztény epitáfium, G. B. De Rossi szerint „a keresztény feliratok királynője. ${ }^{96}$ De nem mindenki osztotta ezt a véleményt: A. von Harnack például úgy találta,

95 Ramsay, CB II. 720. no. 656.

96 „Regina delle iscrizioni cristiane”, G. B. De Rossi: Il cippo sepolcrale di Abercio collocato nel Museo Lateranense. BAC 5 (1894) 65-69, kül. 65. 
hogy a szöveg a pogány-keresztény szinkrétizmus terméke; ${ }^{97}$ G. Ficker, A. Dietrich és R. Reitzenstein pedig amellett érveltek, hogy Aberkios az Attis-Kybelé-kultusz papja volt: a feliraton szereplő „szent pásztor” Attis; az „aranyköpenyes, aranyszandálos királynő” Kybelé római kultuszszobra; a „fényes pecséttel megjelölt nép” Attis-Kybelé római kultuszközössége; Pál pedig Aberkios egyik „beavatott” útitársa. ${ }^{98}$ Ezek az elrugaszkodott elméletek azonban szerencsére a tudománytörténet lomtárába kerültek, és mára teljes a konszenzus abban, hogy a felirat egy „kriptokeresztény” szöveg. Az epitáfiumban szereplő utalások ugyanis pontról pontra megfejthetők az Újszövetség, az egyházatyák írásai és keresztény szimbolika segítségével. Kezdjük a legegyértelműbb utalásokkal: „a

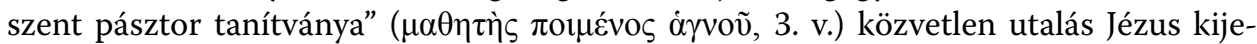

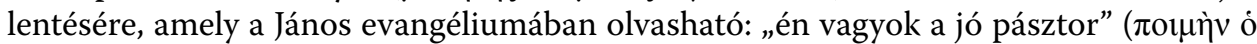
$\kappa \alpha \lambda o ́ \varsigma, ~ J n ~ 10,11.14)$, de közvetlenül ehhez rendelhető a „juhnyáj” kifejezés is, amely a hívők közösségét jelenti (Mt 26,31; Jn 10,2-16; 10,26; 21,16-17; Apcs 20,28 stb.). Ugyan-

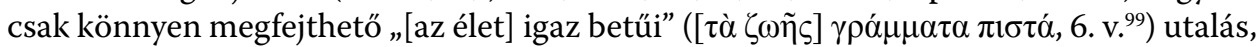
amely több igéből kontaminálódott: a $\gamma \rho \alpha ́ \mu \mu \alpha \tau \alpha$ („betűk”) bevett utalás a Szentírásra

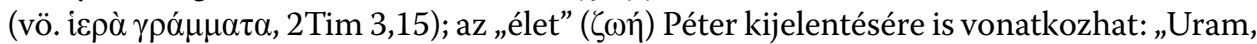

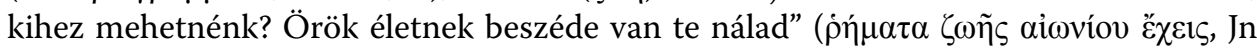

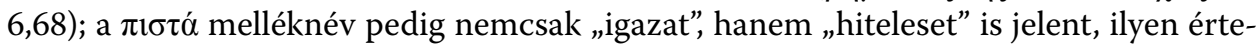

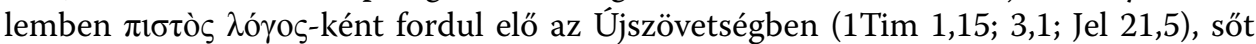
már a Septuagintában is (Zsolt 114,13a LXX). Az Istenre vonatkozó „akinek hatalmas

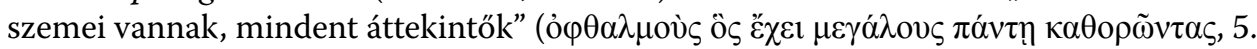
v.) kifejezés nem közvetlen bibliai idézet (a „hatalmas szemek”-nek nincs is bibliai alapja), leginkább a Zak 4:10-ben szereplő: „az Úrnak szemei ezek, a melyek átpillantják az

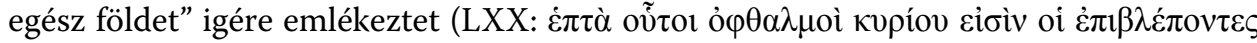

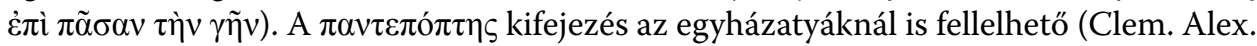
Paed. III. 8. $\$ 44,1)$, de a feliratban szereplő $\kappa \alpha \theta$ o $\tilde{\omega} v \tau \alpha \varsigma$ akár közvetlen homérosi hatás is lehet, ami nem meglepő a phrygiai keresztény feliratok esetében (Zeusról: Hom. Il. XI, 337; XIII, 4). A felirat több enigmatikus kijelentése is egyértelműen a keresztény egyházra érthető: a bevezetésben szereplő „a választott város polgára” ([’] $] \lambda \varepsilon \kappa \tau \tilde{\eta} \varsigma \pi o ́ \lambda \varepsilon \omega \varsigma$ ó

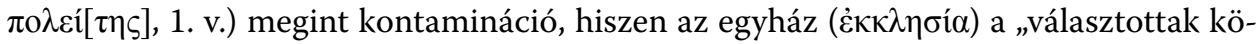

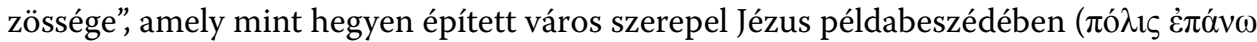

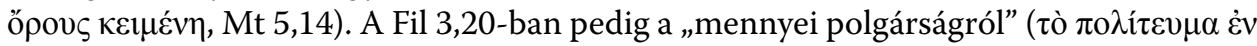
oủpavoĩs) beszél Pál apostol. A 9. versben szereplő „láttam a fényes pecséttel megjelölt

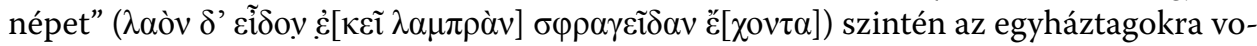
natkozó eszkhatológiai utalásként értelmezhető. A Jelenések könyvében Isten adja ki a

97 A. von Harnack: Zur Abercius-Inschrift (Texte und Untersuchungen XII). Leipzig (1895).

98 G. Ficker: Der heidnische Charakter der Abercius-Inschrift. Sitzungsberichte der königlich preußischen Akademie der Wissenschaften 1 (1894) 87-112; A. Dieterich: Die Grabschrift des Aberkios. Leipzig (1896); R. Reitzenstein - H. H. Schaeder: Studien zum antiken Synkretismus aus Iran und Griechenland. Leipzig (1926) I. 125.

99 A coniecturához lásd R. Merkelbach: Grabepigramm und Vita des Bischofs Aberkios von Hierapolis. EA 28 (1997) 125-139. 
parancsot angyalainak: „ne ártsatok se a földnek, se a tengernek, se a fáknak addig, míg

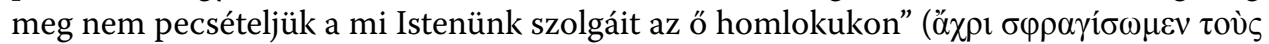

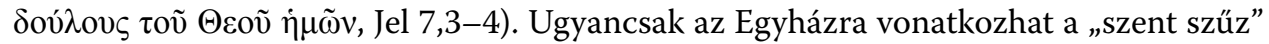
( $\pi \alpha \rho \theta \varepsilon ́[v o \varsigma \alpha \dot{\alpha} v \eta ́]$, 14. v.) kifejezés. Pál több levelében is szűz menyasszonyként jelenik meg a hívők közössége, például „mert isteni buzgósággal buzgok értetek; hisz eljegyeztelek titeket egy férfiúnak, hogy mint szeplőtlen szűzet állítsalak a Krisztus elé” (2Kor 11,2). A 13-14. sorban azt olvassuk: „mindenütt ételt tettek elém: halat a forrásból, /

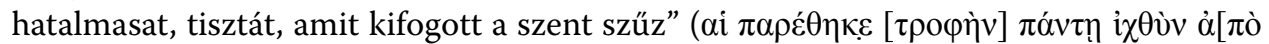

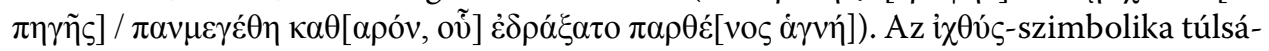
gosan is jól ismert ahhoz, hogy itt ki kelljen térnünk rá, ${ }^{100}$ viszont az ehhez kapcsolódó halászat szintén az egyház tevékenysége: Péternek és Andrásnak azt mondja Jézus, hogy

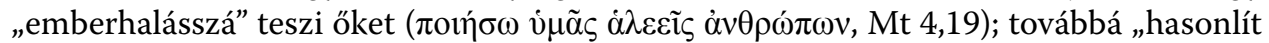
a mennyek királysága a kerítőhálóhoz is, amelyet bevetettek a tengerbe, és mindenféle fajtából fogott” (Mt 13,47). A 16. sorban szereplő „volt jó bora, kevert [bort] adott ke-

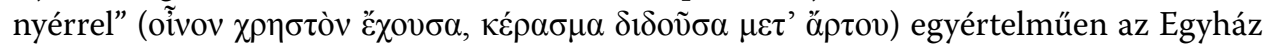
életének egyik fontos tevékenységére, az eucharistiára, vagyis az úrvacsorai közösségre történő utalás (vö. Mt 26,26-28; In 6,53-56; 1Kor 11,23-26). Aligha kétséges, hogy a

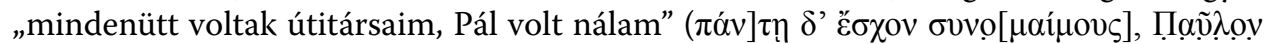

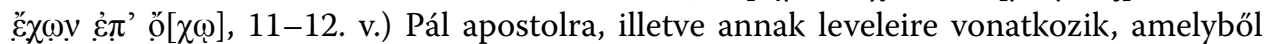

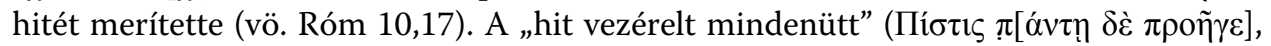
12. v.) kifejezés ismét egy kontamináció: „akiket Isten Lelke vezérel, azok Istennek fiai” (Róm 8,14), illetve az „igaz ember hitből él” (Róm 1,17b); vagy a „hitben járunk, nem látásban” (2Kor 5,7) páli kijelentések vonódtak össze ebben a mondatban.

Akakios sírfelirata Kr. u. 350 körül íródott, egy márványtáblán került elő Appia (Pınarcık), Soa (Altıntaş) vagy Kotianion (Ada Köy) településen. ${ }^{101}$

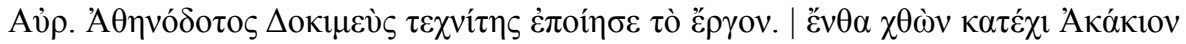

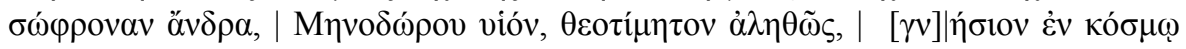

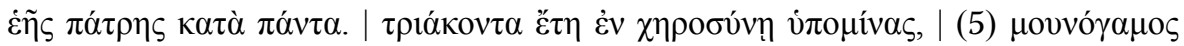

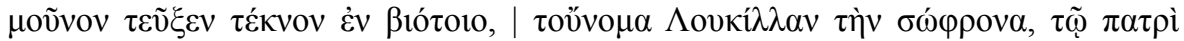

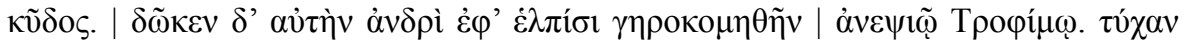

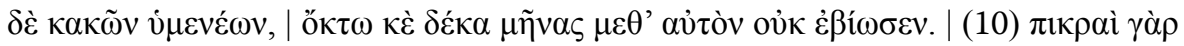

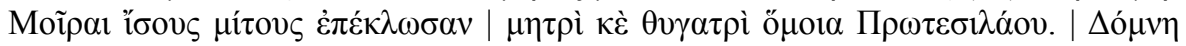

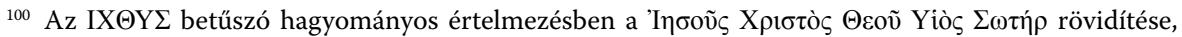

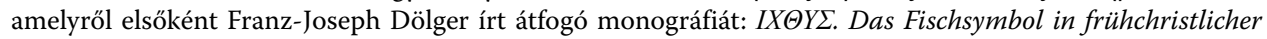
Zeit. Religionsgeschichtliche und epigraphische Untersuchungen, amelynek öt kötete jelent meg 1910 és 1943 között. A legújabb szakirodalomból egy érdekes felvetés: T. Rasimus: Revisiting the Ichthys: A Suggestion Concerning the Origins of Christological Fish Symbolism. In: Mystery and Secrecy in the Nag Hammadi Collection and Other Ancient Literature: Ideas and Practices. Eds. C. H. Bull - L. Lied - J. D. Turner. Leiden (2011) 327-348.

101 SEG XV, 796 = XXX, 1484 = SGO III 16/31/15, a kő méretei: 106 cm magas, 62 cm széles, $14 \mathrm{~cm}$ vastag, a betűk magassága 1,6-2 cm, jelenleg a Kütahya Régészeti Múzeumban őrzik. 


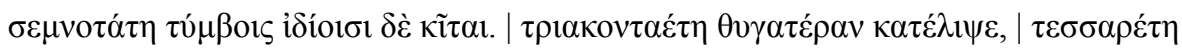

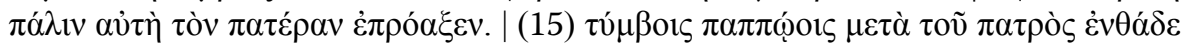

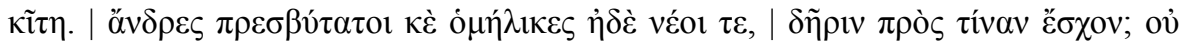

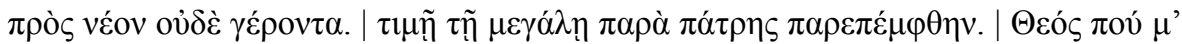

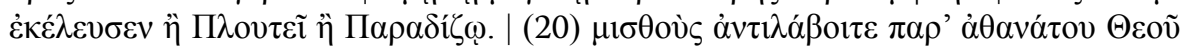

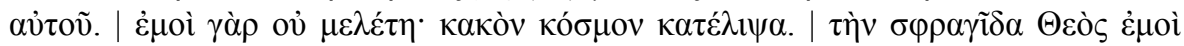

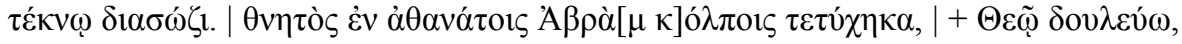

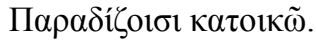

Itt őrzi lent a föld Akakiost, a jámbor férfit, Ménodóros fiát, akit Isten valóban becsült, s aki minden tekintetben tiszteletben állt szülővárosában. (5) Harminc évet élt özvegységben, egyetlen házasságában egyetlen gyermeket nemzett életében, kinek neve Lukilla, a jámbor, apjának dicsősége, férjhez adta őt, abban a reményben, hogy idős szüleit fogja gondozni, unokatestvéréhez, Trophimoshoz. De balszerencsés volt ez a nász: (10) tizennyolc hónapot sem élt férje után. Mert az irigy Moirák egyenlő szálakat fontak anyának és lányának, hasonlót Prótesilaoséhoz. A legtiszteletreméltóbb Domné a saját sírjában nyugszik. Harmincévesen hagyta hátra a lányát, (15) aki viszont apját négy évvel előzte meg, ősi sírban nyugszik itt az apával. Férfiak - idősek, egykorúak és ifjak -, kivel hadakoztam én? Sem ifjúval, sem időssel! Nagy tiszteletben bocsáttattam el a hazámból, (20) ahová Isten parancsolt engem: vagy Plútóhoz, vagy a Paradicsomba. A halhatatlan Istentől kapjátok meg béreteket! Nekem már mindegy: elhagytam a gonosz világot. A pecsétet, nekem, gyermekének, biztosítsa az Isten! Halandóként a halhatatlanok közé, Ábrahám kebelébe kerültem, (25) Istennek szolgálok, a Paradicsomban lakom.

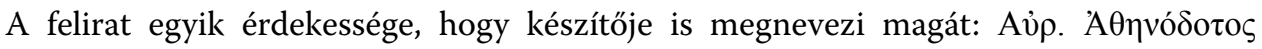

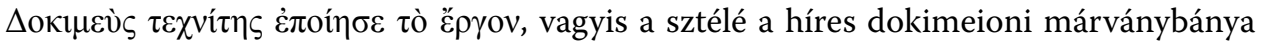
egyik kőfaragójának, Aurelios Athénodotosnak mühelyéből került ki. A 24 hexameteres sor ${ }^{102}$ szerzője egyértelműen keresztény: ezt jelzi az utolsó sor elején elhelyezett kereszt, valamint az Akakios „beszélő név” is, amelynek jelentése: „rossztól mentes, ártatlan”. A 2-16. sorban a család történetét kapjuk: az apa, Akakios, Ménodóros fia, felesége Domné, lányuk Lukilla, aki férjhez ment unokatestvéréhez, Trophimoshoz. Akakios harminc évig élt özvegységben, lánya négy évvel apja előtt hunyt el, harmincévesen. Ebből az következik, hogy Lukilla mindössze négyéves volt, amikor anyja meghalt. Nem derül ki, hogy a lány hány évesen ment férjhez, de férjét csak másfél évvel élte túl. Az egyszerü

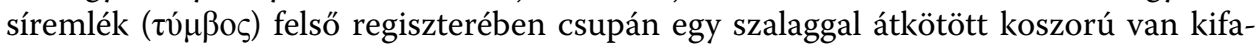
ragva, egyéb ábrázolás nincs rajta, amit már Merkelbach is annak lehetőségeként értelmezett, hogy az elhunyt valamelyik keresztény szektához tartozott. Ezt csak megerősíti, hogy az 5. sorban büszkén hirdeti: „harminc évet élt özvegységben”, ami a montanisták

102 A vers metrumát és szerkezetét elemezte: B. M. Palumbo Stracca: Metro ionico per l'eresia di Ario. Orpheus 11 (1990) 65-83, kül. 74-79. 
felé mutat, akik híveik számára tiltották az újraházasodást. ${ }^{103}$ Az epitáfium nyelve erősen

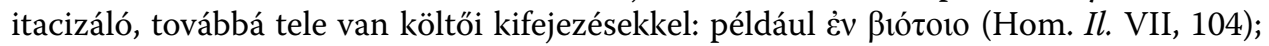

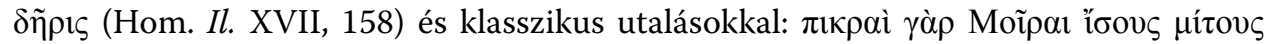

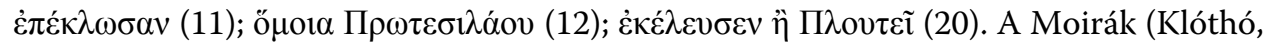
Lakhésis és Atropos) a görög sorsistennők, akik az emberi sors fonalát sodorják, fonják

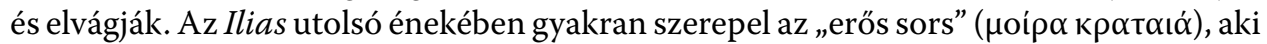
elvágja a hősök sorsának fonalát (például Il. XXIV, 131, 209). A 12. sorban említett thessaliai hős, Prótesilaos volt az első, aki Trója földjére lépett, és ugyancsak ő volt az első, aki a görögök közül meghalt a háborúban. A mítosz szerint felesége, Laodameia addig könyörgött az isteneknek, amíg megengedték, hogy Prótesilaos néhány órára visszatérjen az élők közé, ami után másodszor is meghalt, és felesége is követte a halálba. A keresztény sírfeliratok is gyakran említik Hádést, az Alvilágot, amely ezen a néven a héber Seól megfelelője a Septuagintában (például Ézs 38,18) és az Újszövetségben (Lk 16,23; Apcs 2,27; 1Kor 15,55; Jel 1,18; 20,13-14 stb.). Ugyanakkor meglepő, hogy a 20. sorban nem a Hádést, hanem annak istenségét, Plutónt találjuk. ${ }^{104}$ A költői nyelv és a klasszikus mitológiai utalások mellett bőségesen találunk újszövetségi idézeteket és allúziókat is a szövegben. A „kivel hadakoztam én? Sem ifjúval, sem időssel” (18) hátterében Calder szerint a hetedik boldogmondás állhat: „boldogok a békességszerzők”, bár ez nem bizonyos. ${ }^{105}$ A 21 . sorban szereplő „Halhatatlan Isten” Pálnál is szerepel (1Tim 1,17), a

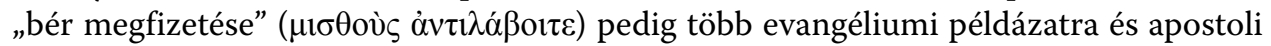
tanításra is utalhat („a ti fizetségetek bőséges a mennyben”: Lk 6,23; „méltó a munkás az ő bérére”: Lk 10,7; „a plántáló és az öntöző egyek, de mindegyik a maga fizetségét kapja meg a maga munkája szerint”: 1 Kor 3,8 stb.). A 22. sorban olvasható „elhagytam a go-

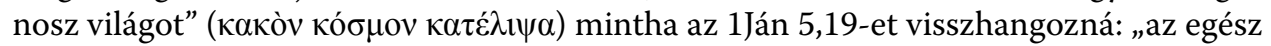

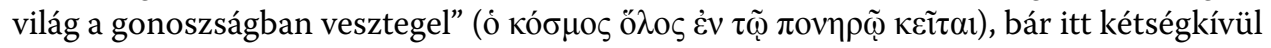

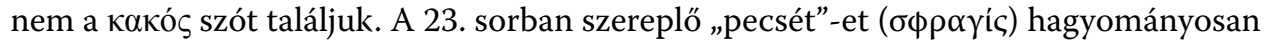
a vízkeresztségre értik a kommentárok, ${ }^{106}$ ami ebben az értelemben szerepel az Aberkios-feliratban is, és Tertullianusnál számtalan helyen, valószínủleg az 1Kor 1,22-re vezet-

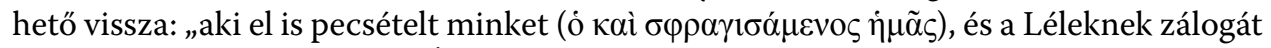
adta a mi szíveinkbe”. ${ }^{107} \mathrm{Az}$ „Ábrahám kebelébe kerültem” és a „Paradicsomban lakom”

103 W. M. Calder: Early-Christian Epitaphs from Phrygia. AS 5 (1955) 25-38, kül. 33. A szerző is felveti ezt a lehetőséget, de aztán inkább úgy dönt, hogy „biztonságosabb” ortodoxnak tartani: „it is safer to treat Akakios as an Orthodox churchman".

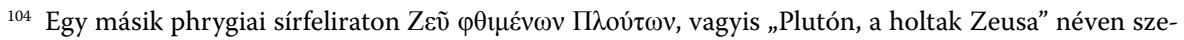
repel $(M A M A$ X, no. 60 = SGO III 16/01/37); az ugyancsak keresztény Aurélios Trophimos sírfeliratán pedig

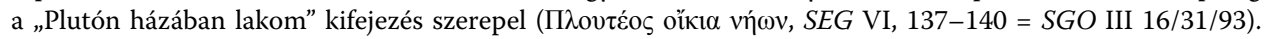
Hierapolisban egy felirat (SEG LXIII, 122) segítségével a régészeknek sikerült a Plutónion nevű szentélyt is azonosítaniuk: F. D’Andria: Il Ploutonion a Hierapolis di Frigia. MDAI(I) 63 (2013) 157-217.

105 Calder: $i . m$. (103. j.) 32.

106 „The epitaph ends with a reference to the Seal of baptism, the passport to Paradise”, Calder: $i$. $m$. (103. j.) 33.

107 G. W. H. Lampe: The Seal of the Spirit. A Study in the Doctrine of Baptism and Confirmation in the New Testament and the Fathers. London (1951). 
megfejtése nem okoz fejtörést, az „Istennek szolgálok” pedig számos újszövetségi igehelyre vezethető vissza (például Lk 16,22; 23,43; 2 Tim 1,3). Teológiai szempontból roppant érdekes, hogy a 20. sorban mintha nem tudná eldönteni, hogy Isten az Alvilágba

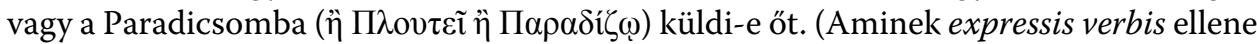
mond a 25. sorban, ahol kijelenti: „a Paradicsomban lakom”.) A Hádés és a Paradicsom természetesen lehetnek szinonim fogalmak is, hiszen Jézus a Lk 23,43-ban az Alvilág-

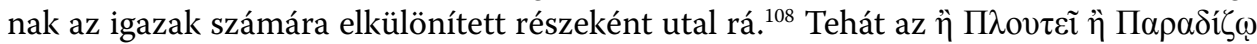
ugyanarra a helyre is vonatkozhat: nevezetesen az Alvilágra, illetve annak egy elkülönített részére, amely a „boldogok lakhelye”, s amit „Ábrahám kebelének” is mondtak. ${ }^{109}$ Ugyanakkor Pál azt mondja, hogy hallott egy emberről, aki „elragadtatott a harmadik égig” vagyis „a Paradicsomba” (2Kor 12,2.4), aminek alapján a Mennyben is kell lennie egy Paradicsomnak. ${ }^{110}$ Teológiai szempontból ebben az egészben az a furcsa, hogy az Újszövetség alapján egyértelmű, hogy Jézus Krisztus feltámadása után „megnyitotta az Eget” az igazak - elsősorban a Krisztusban elhunyt igaz keresztények - számára, vagyis akik korábban az Alvilágba, Ábrahám kebelébe (vagy a Paradicsomba) kerültek, azoknak lelke ettől kezdve a mennyei Paradicsomba szállt. Akármelyik keresztény felekezethez is tartozott Akakios, szinte elképzelhetetlen, hogy erről a hatalmas változásról ne

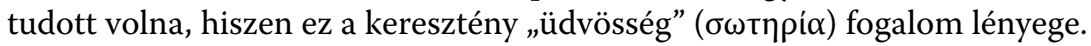

\subsection{Jóslás a Bibliából és Homérosból}

A fentiekben láttuk, hogy a phrygiai keresztények - tartozzanak bármely felekezethez - a legnagyobb természetességgel idézik sírfelirataikon úgy a Bibliát, mint a homérosi eposzok szövegeit. Az alábbi verses epitáfium különlegessége, hogy az abban megörökített Zósimos talán zsidó származású lehetett, aki bibliomanteiával, vagyis könyvekből végzett jóslással foglalkozott. Hogy milyen könyvekből jósolt, az eddigiek alapján könnyen kitalálható: a Bibliából és Homérosból (SEG XLIII, 945 = SGO III 16/41/09, Yapildag).

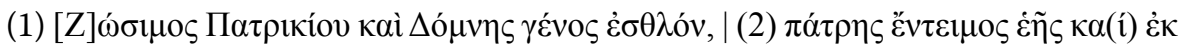

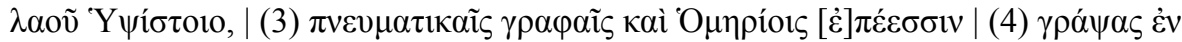

108 Az Alvilág (Seól/Hádés) sem a zsidó, sem a görög elképzelések szerint nem volt homogén hely, például itt volt az „Ábrahám kebele”, ami a görög mitológiában megfelel a „boldogok lakhelyének” vagy az „elysioni mezőknek”. A gazdag ember és a szegény Lázár példázatából kiderül, hogy az Ábrahám kebelét egy hatalmas szakadék választotta el a Seól többi részétől (Lk 16,26).

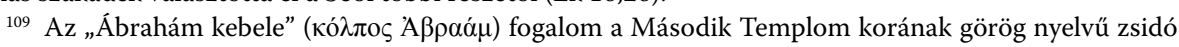
irodalmában bukkan fel, például 4Makk 13:17; Apoc. Zeph. 11,1-2; az epigráfiai forrásokban: I. Kajanto: The Hereafter in Ancient Christian Epigraphy and Poetry. Arctos 12 (1978) 27-53; az egyházatyáknál lásd L. J. van der Lof: Abraham's Bosom in the Writings of Irenaeus, Tertullian and Augustine. AugStud 26 (1995) 109-123.

110 M. Bockmuehl - G. G. Stroumsa (eds.): Paradise in Antiquity: Jewish and Christian Views. Cambridge (2010). 


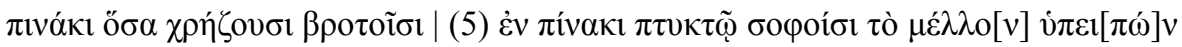

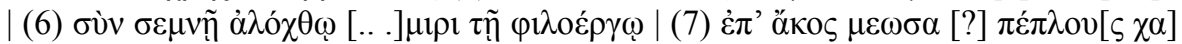

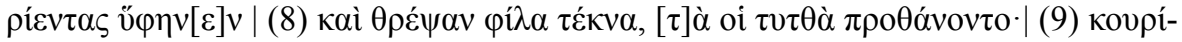

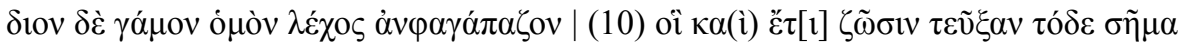
$\kappa \lambda \varepsilon \varepsilon v o ́ v$.

Zósimos, Patrikios és Domna fia, derék sarj, | szülővárosának megbecsült (tagja), s aki a Magasságos népéből való, | szellemi írásokkal és homéroszi eposzokkal | táblára írta, amire csak szüksége van a halandóknak, | (5) összehajtott táblán a bölcseknek a jövőt előre megmondva. | Tiszteletre méltó hitvesével, a munkakedvelő [...]mirisszel, | (aki) gyógyírnak [?] gyönyörű peplosokat szőtt | és kedves gyermekeket nevelt, akik kicsivel elötte haltak meg, | mindketten egyformán szerették a hitvesi ágyat, | (10) és még életükben emelték ezt a nevezetes síremléket.

Ki lehet Zósimos, Patrikios (Patricius) és Domna fia? A név igen gyakori a görög világban, jelentése „élő; élettel teli; túlélő”, az anyai nevet G. Staab kifejezetten zsidó erede-

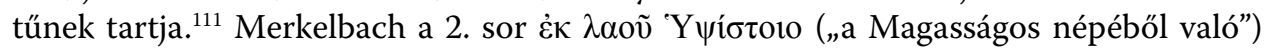

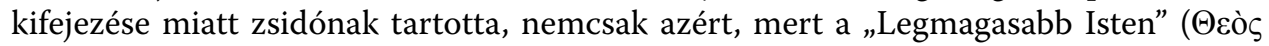
"Y $\psi 1 \sigma \tau о \varsigma)$ a diaszpórában élő zsidók egyik leggyakoribb kifejezése volt a JHVH istennév

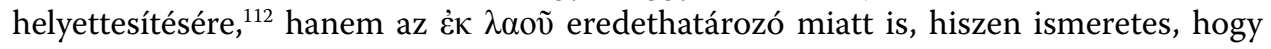
a zsidó feliratokon mekkora hangsúlyt helyeznek a „nép” ( $\lambda \alpha o ́ \varsigma)$ áldására. Zósimos ez

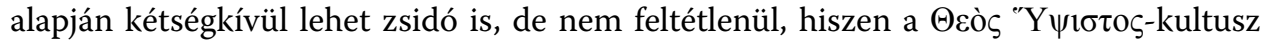

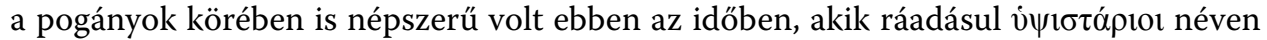
vallási társulatokat is müködtettek. ${ }^{113}$ Merkelbach nem tért ki a 3. sor elején olvasható „szellemi írások” ( $\pi v \varepsilon v \mu \alpha \tau \imath \kappa \alpha i ̀ ~ \gamma \rho \alpha \varphi \alpha i ́)$ jelentésére sem, pedig ez is segíthet a vallási af-

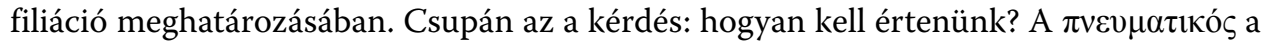
montanisták kedvelt kifejezése, amit ők a Szent Lélekre (Szellemre) vonatkoztattak. Az ő felfogásuk szerint - amit a Júd 1,19-re vezetnek vissza - kétféle Egyház létezik: a „szellemi” ( $\pi v \varepsilon v \mu \alpha \tau \iota \kappa o ́ \varsigma)$ és a „lelki” ( $\psi v \chi \imath \kappa o ́ \varsigma)$. A „szellemi írások” kifejezés a 2Tim 3,16-ból is

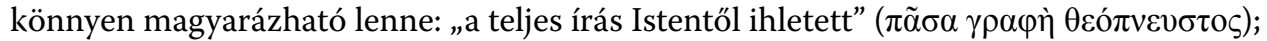
miközben hasonló szöveget nem találunk a Septuagintában. Ha tehát erre az újszövetségi helyre utal, akkor a „szellemi írások”-on nyilvánvalóan a Bibliát kell értenünk.

111 Staab: $i . m$. (67. j.) 59. n. 174: „der Name der Mutter, $\Delta$ ó $\mu v \alpha$, könnte hier, wenn auch nicht generell, von seinem semitischen Ursprung (arab. Dumayna) her aufgefaßt werden”. Domna az ókori zsidó nevek lexikonában is szerepel: T. Ilan: Lexicon of Jewish Names in Late Antiquity, Part III (TSAJ 126). Tübingen (2008) 580 .

112 Theos Hypsistosra hivatkoznak az alábbi phrygiai feliratok is: $S G O$ III 08/08/13 Hadrianoi pros Olympon; SGO III 10/03/01, Amastris; SGO III 14/05/02, Aralleia; SGO III 14/07/04, Ikonion; vö. Zqvì $\pi \alpha v v \psi i ́ \sigma \tau \omega$, SGO III 16/44/01, Phyteia. Staab: $i$. m. (67. j.) 59 szintén a zsidó eredet bizonyítékának veszi.

113 Ráadásul Grégorios Nazianzénos szerint éppen ezen a területen még a IV. században is (Orat. XVIII, 5, Kr. u. 374 k.). S. Mitchell: The Cult of Theos Hypsistos Between Pagans Jews and Christians. In: Pagan Monotheism in Late Antiquity. Eds. P. Athanassiadi - M. Frede. Oxford (1999) 81-148. 
Miben állt tehát Zósimos tevékenysége? Abban, hogy „homéroszi eposzokkal táblára írta, amire csak szüksége van a halandóknak, összehajtott táblán a bölcseknek a jövőt előre megmondva”, egyszerűbben mondva a homéroszi eposzokból jósolt. A jövendömondásnak ez a formája a bibliomanteia néven volt ismert, amit egyaránt műveltek Homérosszal, Vergiliusszal és a Bibliával. Cassius Dio a II-III. században a szíriai Apameiában, Zeus Bélos szentélyében találkozott egy pappal, aki Homéros soraiból jósolt, ${ }^{114}$ de a jóslásnak ez a formája - Szent Ágoston egy megjegyzéséből következtetve (Epist. LV, 20, 37) - a keresztények között még a IV-V. században is népszerű lehetett. ${ }^{115}$ Egyébként Zósimos valóban betéve ismerhette az eposzokat, hiszen sírfelirata telis-tele van

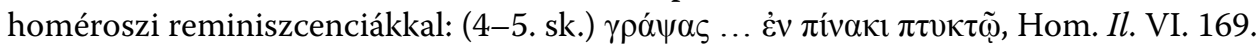
Bellerophón történetére utal;116 (7. s.) ö́os „gyógyír”, Hom. Od. XXII, 481. stb.; (7. s.)

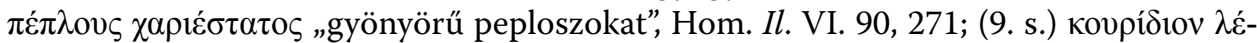

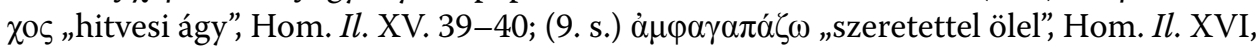
192, Od. XIV, 381. A literalizáció szempontjából érdemes megjegyezni, hogy Zósimos a

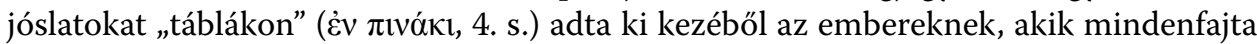

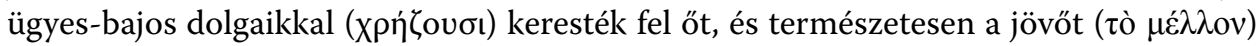
is tudakolták. Ez mintha megerősítené azt, hogy az olvasás a tekercshez ( $\beta 1$ í pedig a táblához ( $\pi$ ív $\alpha \xi)$ kötődött. A sírvers $6-10$. sora az ismeretlen nevü feleséghez kötődik, akit derék asszonyként mutat be, akinek három erénye a szövés, a gyermeknevelés és a férje iránti odaadó (és kölcsönös) szeretet. Nem mondhatjuk, hogy ez csak zsidó vagy keresztény erény, hiszen a görög-római kultúra egyaránt ezeket az erényeket tisztelte a legjobban a feleségekben.

\section{7. Összegzés}

Az egykori Római Birodalom területén fennmaradt síremlékek sajátos módon tükrözik egy-egy régió népességének vallási-kulturális identitását. A phrygiai epitáfiumok esetében első pillantásra szembetűnő az íróanyagok (papirusztekercs, írótábla) és íróeszközök (stylus, tolltartó) gyakori ábrázolása lényegében az összes síremléktípuson.

114 Dio LXXIX, 8, 6; LXXIX, 40, 3.

115 M Dillon: Omens and Oracles: Divination in Ancient Greece. New York - London (2017) 271; P. W. van der Horst: Sortes: Sacred Books as Instant Oracles in Late Antiquity. In: The Use of Sacred Books in the Ancient World. Eds. L. V. Rutgers et al. Hadleigh (1998) 143-173; F. Naether: Die Sortes Astrampsychi. Tübingen (2010) 330-331; A. Chaniotis: „The Best of Homer”: Homeric Texts, Performances, and Images in the Hellenistic World and Beyond. The Contribution of Inscriptions. In: Homer: Myths, Texts, Images. Homeric Epics and Ancient Greek Art. Ed. E. Walter-Karydi. Ithaca (2010) 257-278; A. Karanika: Homer the Prophet: Homeric Verses and Divination in the Homeromanteion. In: Sacred Words: Orality, Literacy and Religion. Eds. A. H. M. Lardinois - J. H. Blok - M. G. M. van der Poel. Leiden (2011) 255-278. A homéromanteia gyakorlata egyiptomi papiruszokból is jól ismert, például P.Oxy. 3831, III-IV. század.

${ }_{116}$ „Er sagte den »Klugen« die Zukunft, vielleicht in verschlüsselter Form, die nur von den Klugen verstanden wurde” (Merkelbach). 
A SGO III. kötete 287 darab verses feliratot közölt Phrygia területéről, amelynek többsége a II-III. században keletkezett. A feliratok megoszlásában megfigyelhetők ugyan regionális különbségek (például kiugróan magas a Tembris-völgyben előkerült metrikus feliratok száma ${ }^{117}$ ), de alapvetően az urbánus és rurális területek között nincs számottevő különbség. Közös jellegzetesség az is, hogy a feliratok nyelve archaizáló, még a legegyszerűbb kifejezéseket is Homérostól kölcsönzik, függetlenül attól, hogy a felirat állítói a görög-római isteneket tisztelik, vagy keresztények. Az utóbbi csoport esetében - jelenlegi ismereteink szerint az egész római világban egyedülálló módon - szimbolikus értelmű szövegekbe rejtik hovatartozásukat („kriptokeresztény feliratok”), de már a II. század végétől akár nyíltan is kifejezik kereszténységüket. (A III. századtól pedig még felekezeti hovatartozásukat sem rejtik véka alá.) Ezzel függ össze, hogy a zsidók és keresztények egyformán idézik a Bibliát epitáfiumaikban: burkoltan vagy nyíltan, szó szerint vagy parafrazeálva. Valószínű, hogy a kereszténység előretörésének hatására - erről már Kr. u. 110/111-ben Bithynia vonatkozásában részletesen beszámolt ifjabb Plinius ${ }^{118}$ - jött létre egy sajátos, új epigráfiai müfaj: a konfessziós felirat, amelyben a régi vallás hívei saját isteneik „működőképességéről” adnak számot nyíltan, feliratos sztélék formájában, melyeknek készítésére kifejezetten az istenektől kapnak utasítást. Phrygiában - különösen a Felső-Tembris-völgy kisfalvas térségében - jól megfigyelhető a különféle vallások kölcsönhatása. A sírfeliratok egyik leggyakrabban idézett „átokformulájában”, amivel a sírrablókat igyekeztek távol tartani, jól megmutatkozik ez a jelenség. Az ún. eumeneiai formulát („legyen elszámolnivalója istennel”) egyaránt használták pogányok, zsidók és keresztények: a különbség mindössze annyi volt, hogy kivel/mivel fenyegetőztek: Zeus haragjával vagy a Végítélet napjával. Figyelemre méltó ugyanakkor, hogy ebben a vallási és kulturális szempontból rendkívül összetett térségben semmi jele a vallások hívei közti ellenségeskedésnek.

117 A metrikus feliratok regionális megoszlása is érdekes: Délnyugat-Phrygia (Maiandros-völgy): $31 \mathrm{db}$; Északnyugat-Phrygia (Makéstos-, Rhyndakos- és Hermos-völgy): 35 db; Észak-Phrygia (Tembris-völgy): 120 db; Phrygiai Felföld és Kelet-Phrygia (Parthenios- és Sangarios-völgy): 45 db; Délkelet-Phrygia: 56 db.

${ }_{118}$ Epist. X, 96, 9: multi enim omnis aetatis, omnis ordinis, utriusque sexus etiam vocantur in periculum et vocabuntur. neque civitates tantum, sed vicos etiam atque agros superstitionis istius contagio pervagata est. Phrygia krisztianizálásáról legújabban lásd P. McKechnie: Christianizing Asia Minor: Conversion, Communities, and Social Change in the Pre-Constantinian Era. Cambridge (2019). 


\section{SUMMARY}

Phrygia in Central Anatolia was an area with a rich historical heritage, its own language, and particular culture within the Roman Empire, where literacy and literary education was highly valued. All this is witnessed by hundreds of Greek epitaphs that have come down to us from the period between the second and fourth centuries A.D. A strikingly large number of these funerary monuments depict writing tablets, styluses, pen cases and papyrus scrolls; and nowhere else have so many metrical epitaphs been preserved in the territory of the whole Empire, filled with Homeric reminiscences and classical mythological references. Besides, this is equally typical of the inhabitants of urban and rural areas - simple farmers and stockbreeders - as well. Poetic epitaphs in an epic language were popular among both the devotees of the Greco-Roman religion and Christians. And naturally, the latter expanded their literary repertoire with Biblical quotations and allusions as early as 150 years prior to the religious peace of Constantine's reign.

Keywords: Phrygia, epigraphy, metrical epitaphs, intertextuality, literacy, Homer, Bible

\section{GRÜLL TIBOR}

Pécsi Tudományegyetem, Történettudományi Intézet, Ókortörténeti Tanszék

7624 Pécs, Rókus utca 2.

grull.tibor@pte.hu

Open Access. A cikk a Creative Commons Attribution 4.0 International License (https://creativecommons.org/licenses/by/4.0) feltételei szerint publikált Open Access közlemény, melynek szellemében a cikk bármilyen médiumban szabadon felhasználható, megosztható és újraközölhető, feltéve, hogy az eredeti szerző és a közlés helye, illetve a CC License linkje és az esetlegesen végrehajtott módosítások feltüntetésre kerülnek. (SID_1) 